Eur J Nutr (2020)

https://doi.org/10.1007/s00394-020-02298-X

\title{
Individual participant data (IPD)-level meta-analysis of randomised controlled trials with vitamin D-fortified foods to estimate Dietary Reference Values for vitamin D
}

Kevin D. Cashman ${ }^{1}$, Mairead E. Kiely ${ }^{1}$, Rikke Andersen ${ }^{2}$, Ida M. Grønborg ${ }^{2 *}$, Katja H. Madsen $^{2 *}$, Janna Nissen ${ }^{2 *}$, Inge Tetens ${ }^{2 *, 3}$, Laura Tripkovic ${ }^{4 *}$, Susan A. Lanham-New ${ }^{4}$, Laura

Toxqui $^{5^{*}}$, M. Pilar Vaquero ${ }^{5}$, Ulrike Trautvetter ${ }^{6}$, Gerhard Jahreis ${ }^{6}$, Vikram V. Mistry ${ }^{7}$, Bonny L. Specker ${ }^{8}$, Jürgen Hower ${ }^{9}$, Anette Knoll ${ }^{10}$, Dennis Wagner ${ }^{11}$, Reinhold Vieth ${ }^{11,12}$, Inger Öhlund $^{13}$, Pia Karlsland Åkeson ${ }^{14}$, Neil R. Brett ${ }^{15}$, Hope A. Weiler ${ }^{15}$, Christian Ritz ${ }^{3}$

${ }^{1}$ Cork Centre for Vitamin D and Nutrition Research, School of Food and Nutritional Sciences, University College Cork, Cork, Ireland;

${ }^{2}$ Research Group for Risk-Benefit, Division for Diet, Disease Prevention and Toxicology,

National Food Institute, Technical University of Denmark, Kgs. Lyngby, Denmark;

${ }^{3}$ Department of Nutrition, Exercise and Sports, Faculty of Science, University of Copenhagen, Frederiksberg C, Denmark.

${ }^{4}$ Department of Nutritional Sciences, School of Biosciences and Medicine, Faculty of Health and Medical Sciences, University of Surrey, Guildford, United Kingdom;

${ }^{5}$ Institute of Food Science, Technology and Nutrition (ICTAN-CSIC), Madrid, Spain;

${ }^{6}$ Institute of Nutrition, Friedrich Schiller University of Jena, Dornburger Str, 24, D-07743, Jena, Germany;

${ }^{7}$ Dairy Science Department, South Dakota State University, Brookings 57007, USA;

${ }^{8}$ Ethel Austin Martin Endowed Program in Human Nutrition, South Dakota State University, Brookings 57007, USA;

${ }^{9}$ Überörtliche Gemeinschaftspraxis für Kinder- und Jugendmedizin Standort Dümpten, Mellinghofer Straße 256, 45475 Mülheim an der Ruhr, Germany,

${ }^{10}$ Freelance Statistician, Kreppe 2, 85276 Pfaffenhofen/Ilm, Germany;

${ }^{11}$ Department of Nutritional Sciences, University of Toronto, M563E2 Toronto, and

${ }^{12}$ Department of Pathology and Laboratory Medicine, Mount Sinai Hospital, M5G1X5 Toronto, Canada;

${ }^{13}$ Department of Clinical Sciences, Pediatrics, Umeå University, Umeå, Sweden;

${ }^{14}$ Department of Clinical Sciences, Pediatrics, Lund University, Lund, Sweden;

${ }^{15}$ School of Human Nutrition, McGill University, Sainte Anne de Bellevue, Quebec, Canada;

*Address at the time when the original intervention study was conducted.

\section{Contact details:}


Professor Kevin Cashman,

Cork Centre for Vitamin D and Nutrition Research, School of Food and Nutritional Sciences, and Department of Medicine, University College Cork, Ireland.

甶: +353 21 4901317; $ه$ : k.cashman@ucc.ie; ORCID: orcid.org/0000-0002-8185-1039

Running head: $\quad$ IPD-analyses derived vitamin D recommendations

Research Registration: PROSPERO International Prospective Register of Systematic Reviews (registration number: CRD42018097260)

\author{
Abbreviations: \\ 25(OH)D, 25-hydroxyvitamin D \\ AI, Adequate Intake \\ DRI, Dietary Reference Intake \\ DRV, Dietary Reference Values \\ EAR, Estimated Average Requirement \\ EFSA, the European Food Safety Authority \\ FFQ, Food Frequency Questionnaire \\ IOM, Institute of Medicine \\ IPD, Individual Participant Data \\ NNR, the Nordic Council of Ministers' Nordic Nutrition Recommendations \\ RCT, Randomized Controlled Trial \\ RDA, Recommended Dietary Allowance \\ RI, Recommended Intake \\ RNI, Reference Nutrient Intake \\ SACN, the Scientific Advisory Committee on Nutrition \\ UVB, Ultraviolet B \\ WHO-FAO, World Health Organisation-Food and Agriculture Organization \\ SR-MA, Systematic Reviews and Meta-Analyses
}


1 Abstract

2 Context and purpose: Individual participant data-level meta-regression (IPD) analysis is

3 superior to meta-regression based on aggregate data in determining Dietary Reference Values

4 (DRV) for vitamin D. Using data from randomized controlled trials (RCTs) with vitamin $\mathrm{D}_{3-}$

5 fortified foods, we undertook an IPD analysis of the response of serum 25-hydroxyvitamin

$6 \quad(25(\mathrm{OH}) \mathrm{D})$ to total vitamin $\mathrm{D}$ intake during winter among children and adults and derived

7 DRV for vitamin D.

8 Methods: An IPD analysis using data from 1429 participants (ages 2-89 years) in 11 RCTs

9 with vitamin D-fortified foods identified via a systematic review and predefined eligibility

10 criteria. Outcome measures were vitamin D DRV estimates across a range of serum 25(OH)D

11 thresholds using unadjusted and adjusted models.

12 Results: Our IPD-derived estimates of vitamin D intakes required to maintain $97.5 \%$ of

13 winter $25(\mathrm{OH}) \mathrm{D}$ concentrations $\geq 25$ and $\geq 30 \mathrm{nmol} / \mathrm{L}$ are 6 and $12 \mu \mathrm{g} / \mathrm{day}$, respectively

14 (unadjusted model). The intake estimates to maintain $90 \%, 95 \%$ and $97.5 \%$ of concentrations

$15 \geq 50 \mathrm{nmol} / \mathrm{L}$ are $33.4,57.5$ and $92.3 \mu \mathrm{g} /$ day, respectively (unadjusted) and 17.0, 28.1 and 43.6

$16 \mu \mathrm{g} /$ day, respectively (adjusted for mean values for baseline serum $25(\mathrm{OH}) \mathrm{D}$, age and BMI).

17 Conclusions: IPD-derived vitamin D intakes required to maintain 90\%, 95\% and 97.5\% of

18 winter $25(\mathrm{OH}) \mathrm{D}$ concentrations $\geq 50 \mathrm{nmol} / \mathrm{L}$ are much higher than those derived from

19 standard meta-regression based on aggregate data, due to the inability of the latter to capture

20 between person-variability. Our IPD provides further evidence that using food-based

21 approaches to achieve an intake of $12 \mu \mathrm{g} / \mathrm{d}$ could prevent vitamin D deficiency (i.e., serum

$2225(\mathrm{OH}) \mathrm{D}<30 \mathrm{nmol} / \mathrm{L})$.

23

24 Keywords: Vitamin D recommendations; Dietary Reference Values; Recommended Dietary

25 Allowance; Individual Participant Data-level meta-regression analyses; Vitamin D-fortified

26 foods 


\section{Introduction}

There is widespread acknowledgement of the presence of vitamin D deficiency in the general population [1-3]. A serum 25-hydroxyvitamin D (25(OH)D) concentration of $30 \mathrm{nmol} / \mathrm{L}$ represents a cut-off below which the risk of clinical vitamin D deficiency increases, manifesting as nutritional rickets in children and osteomalacia in adults [4]. The prevalence of serum $25(\mathrm{OH}) \mathrm{D}<30 \mathrm{nmol} / \mathrm{L}$ has been recently reported as $13 \%, 8.8 \%$ and $5.0 \%$ for representative population samples in Europe, Canada and the US, respectively $[2,5,6]$. These population-wide prevalence estimates, when coupled with current population size data, crudely suggest 20 and 97 million individuals in the US plus Canada and Europe, respectively, are at increased risk of clinical vitamin D deficiency. Thus, the first key priority from a public health perspective is to ensure that this risk is minimized [1,2]. It should be noted also that beyond deficiency, several $[4,7,8]$, but not all [9], expert bodies briefed with development of dietary recommendations for vitamin D, using musculoskeletal health as the primary basis and some extra-skeletal health outcomes to a much lesser extent, proposed 50 $\mathrm{nmol} / \mathrm{L}$ as the concentration of serum $25(\mathrm{OH}) \mathrm{D}$ that would meet the physiological vitamin $\mathrm{D}$ requirement of nearly all 'normal healthy persons'. While it has also been suggested that in terms of extra-skeletal health, serum $25(\mathrm{OH}) \mathrm{D}$ concentration should exceed $75 \mathrm{nmol} / \mathrm{L}$ [10], a number of recent umbrella reviews in the area [11-13] as well as the findings of some expert bodies $[7,8]$, do not support the assertion that circulating $25(\mathrm{OH}) \mathrm{D}$ concentrations above 50 $\mathrm{nmol} / \mathrm{L}$ are needed by all individuals for the prevention of non-skeletal diseases.

In the absence of sufficient ultraviolet B (UVB) radiation availability and/or exposure to enable vitamin D synthesis in the skin, dietary supply of vitamin D is critical to meeting population requirements and prevention of deficiency [14]. The median of average vitamin D intakes from various national nutrition surveys in Europe was $\sim 3 \mu \mathrm{g} / \mathrm{d}[15,16]$ and $\sim 7 \mu \mathrm{g} / \mathrm{d}$ in Canada and the US $[17,18]$, highlighting how the majority of individuals in these regions, with the exception of some Nordic countries, are considered to have inadequate intakes $[15,17,18]$. This widespread dietary inadequacy is because there are very few rich natural food sources of vitamin D, the major ones being oily fish, egg yolks, and vitamin D-fortified products in some countries $[14,15,18,19]$. In terms of potential strategies for addressing inadequate micronutrient intake, the World Health Organisation-Food and Agriculture Organization (WHO-FAO) have suggested that food fortification has the widest and most 
sustained impact, and thus represents a very cost-effective public health intervention [20].

60

61

62

63

64

65

66

67

68

69

70

71

72

Importantly, two systematic reviews and meta-analyses (SR-MA) have provided a key evidence-base for the efficacy of food fortification in adults in the form of data from up to 16 separate randomized controlled trials (RCTs) from around the world [21,22]. While these provide evidence at the highest level that food fortification increases serum $25(\mathrm{OH}) \mathrm{D}$ in a RCT setting, 12 of the 16 RCTs used dairy products as a food vehicle and 9 of these were milk/milk powder-based [21]. The valuable contribution vitamin D-fortified milk makes to vitamin D intakes, particularly in children, and the continued need for vitamin D fortification of milk and other dairy products is widely acknowledged [23,24]. However, it has been suggested that vitamin D fortification of a wider range of foods, which accommodate diversity, is likely to have the potential to increase vitamin D intakes across the population distribution and minimize the prevalence of low serum 25(OH)D [21,23]. Since the publication of the two SR-MA (7 and 12 y ago [21,22]), and particularly considering the diversification of food vitamin D fortification beyond milk, several new RCTs of vitamin Dfortified foods have been published [reviewed in 14,25]. A recent SR-MA of vitamin D RCTs in children (ages 2-18 y) reported a significantly greater response of serum $25(\mathrm{OH}) \mathrm{D}$ per 2.5 $\mu \mathrm{g}$ vitamin $\mathrm{D}_{3}$ increment/d in trials using fortified foods compared to those with daily vitamin D supplements [26]. While the reason for this finding is not known, it is of note, as internationally the Dietary Reference Values (DRV) or equivalents for vitamin D have for the most part been established using dose-response data from RCTs with vitamin $\mathrm{D}_{3}$ supplements [4,7-9]. Increasingly, the use of individual participant data (IPD)-level meta-regression analysis is recognized as best practice [27], as it avoids some of the limitations intrinsic to standard meta-regression based on aggregate data [28,29]. None of the three SR-MA $[21,22,26]$ had access to individual data from the included RCTs so they were unable to undertake IPD-level meta-regression. Similarly, most recent DRV for vitamin D were based on standard meta-regression of aggregate data $[4,7,8]$, mainly from supplementation trials.

Thus, the aims of the present work were firstly, through the process of a systematic review, to identify RCTs with vitamin $\mathrm{D}_{3}$-fortified foods and subsequently use their individual data to undertake a priority IPD meta-regression analyses of the response of winter serum $25(\mathrm{OH}) \mathrm{D}$ to total vitamin $\mathrm{D}_{3}$ intake in both children and adults. Secondly, to compare our IPD-derived 
vitamin DRV estimates based on vitamin $\mathrm{D}_{3}$-fortified food RCTs with international DRV which were largely based on vitamin $\mathrm{D}_{3}$-supplement RCTs; as well as comparing these estimates with those from our previous IPD (also based on vitamin $\mathrm{D}_{3}$-supplement RCTs).

\section{Materials and methods, including scientific approach}

The methodology in the present work follows the general methodology for systematic reviews as well as the more specialized IPD meta-regression analysis in the area of the vitamin D intake-serum 25(OH)D response applied previously [19,28,30-32], with brief details as follows:

\section{Adherence to IPD guidelines and registration}

The present IPD meta-regression analysis of data from food-based vitamin D RCTs follows the guidance provided as part of the PRISMA (Preferred Reporting Items for Systematic Reviews and Meta-Analyses)-IPD statement [33]. The overall process can be considered a set of sequential steps starting with a systematic review to identify the appropriate vitamin D RCTs and culminating in statistical analyses that estimates the dose-response relationship, and hence the DRV for vitamin D, utilizing the pooled data of individual participants from all included RCTs [28,29,34].

The IPD meta-regression analysis was registered with the PROSPERO International Prospective Register of Systematic Reviews (registration number: CRD42018097260; https://www.crd.york.ac.uk/PROSPERO/display_record.php?RecordID=97260).

\section{Ethics approval}

Approval by a research ethics committee to conduct this meta-analysis was not required because the aim of this secondary analysis was consistent with the ethical approval received for the individual studies. The current analysis was conducted on anonymized data.

\section{Systematic review to identify eligible papers}

\section{Eligibility criteria}


120 The following outlines eligibility criteria for the food-based vitamin D RCTs for inclusion in

121 the IPD-level meta-regression analysis to estimate the DRV for vitamin D. As with our

122 previous IPD [28], the current IPD followed an approach that prioritized the identification of

123 the vitamin D intake values to maintain serum $25(\mathrm{OH}) \mathrm{D}$ concentrations above chosen cut-

124 offs when UVB-induced skin synthesis of vitamin D is absent or markedly diminished. This

125 is closely aligned with the predefined criteria used by the Institute of Medicine (IOM) in their

1262011 Vitamin D and Calcium Dietary Reference Intake (DRI) exercise [4] to select RCTs

127 considered most appropriate to address the specific question of setting dietary requirements

128 for vitamin $\mathrm{D}$ to meet pre-specified $25(\mathrm{OH}) \mathrm{D}$ thresholds and is similar to that taken by the

129 Nordic Council of Ministers' Nordic Nutrition Recommendations (NNR) [8], the Scientific

130 Advisory Committee on Nutrition (SACN) in the UK [9], and the European Food Safety

131 Authority (EFSA) [7].

132

133 Within the Population Intervention Comparison Outcome (PICO) framework [35], the

134 populations of interest in this study were specified as male and female children and adults,

135 but excluding studies in infants (0-12 months) and young toddlers (12-23.9 months), pregnant

136 or lactating women, and dark-skinned individuals (defined as those with a Fitzpatrick skin

137 type of V or VI [34]). These excluded population subgroups have physiological

138 considerations in relation to vitamin D [28] which require dedicated IPD meta-regression

139 analyses [29,34]. Studies on animals and patient groups with diseases that are assumed to

140 affect vitamin D metabolism and/or response to vitamin $\mathrm{D}_{3}$ supplementation (see

141 Supplemental Table 1 in 'Online Resource', as per [28,35]) were excluded. Relevant food-

142 based vitamin D RCTs were defined as those fulfilling the following characteristics:

144 (1) Intervention: vitamin $\mathrm{D}_{3}$ consumed orally as a fortified/enhanced/enriched food(s) and 145 taken daily or weekly. RCTs which supplied vitamin $\mathrm{D}_{3}$-fortified/enhanced/enriched

146 food(s) less frequently than weekly (e.g., monthly, quarterly, annually) were excluded.

147 The foods were to be consumed as part of a diet and not oral supplements, supplement 148 sachets for addition to foods, or be fortified/enhanced/enriched food(s) supplying $\leq 100$ 
IU/d $(2.5 \mu \mathrm{g} / \mathrm{d} ; 1 \mu \mathrm{g}=40 \mathrm{IU})$. Inclusion of RCT arms was limited to those with a maximum added vitamin $\mathrm{D}_{3}$ dose of $4000 \mathrm{IU}(100 \mu \mathrm{g}) / \mathrm{d}$ (or daily equivalent, in case of doses provided less frequently than daily). This selection of upper maximum dose takes account of the Tolerable Upper Intake Level (UL) for vitamin D of 4000 IU/d for those upwards of 9 and $11 \mathrm{y}$, set by EFSA [36] and IOM [4]. The selection of upper maximum dose of $4000 \mathrm{IU} / \mathrm{d}$ also allows for a trend amongst adults for increasing use of higher dose vitamin D supplements [37]. committee and EFSA used studies with vitamin $\mathrm{D}_{3}$ in their regression analyses, to set DRV [4,7], and (ii) there is evidence that the relative potency of vitamin $\mathrm{D}_{2}$ to increase serum total $25(\mathrm{OH}) \mathrm{D}$ is lower than vitamin $\mathrm{D}_{3}[38,39]$. While the IOM only selected studies that provided vitamin D alone and not with co-administration of calcium [4], both the NNR [8] and EFSA [9] allowed studies which co-administered calcium to be included. We have provided RCT data to suggest that calcium intake does not influence the response of serum $25(\mathrm{OH}) \mathrm{D}$ to vitamin $\mathrm{D}_{3}$ supplementation [40] and DRV for vitamin D are established under the assumption that calcium intake is adequate [4,7-9]. Thus, we allowed food-based RCTs that provided vitamin D alone or in combination with calcium to be included. As foods were the delivery vehicle as opposed to supplements, we also allowed other micronutrients (e.g., vitamin K, B-vitamins, iron) to be included in addition to vitamin $\mathrm{D}$ and calcium.

(2) RCTs using a food derived from a 'vitamin D-biofortification' approach, in which $25(\mathrm{OH}) \mathrm{D}_{3}$ alone or in combination with vitamin $\mathrm{D}_{3}$ was included in the feedstuffs for poultry, livestock or farmed fish, which was then incorporated into their tissues and thus in food for human consumption [25,41], were allowed. Otherwise, RCTs with vitamin D metabolites $\left(25(\mathrm{OH}) \mathrm{D}\right.$ and $\left.1,25(\mathrm{OH})_{2} \mathrm{D}\right)$ and analogues (e.g., alfacalcidol) as the human 
(3) Outcome and comparator/comparison: reported serum or plasma 25(OH)D concentration following supplementation in at least one vitamin D intervention group and one control/placebo group needed to be available. A conversion factor of 2.496 $\mathrm{nmol} / \mathrm{L}=1 \mathrm{ng} / \mathrm{mL}$ was used to standardise all serum or plasma concentrations to nmol/L. Studies with no data on measured serum or plasma $25(\mathrm{OH}) \mathrm{D}$ were excluded.

(4) Only studies conducted at latitudes $\geq 40^{\circ} \mathrm{N}$ during, or at least incorporating, winter, to ensure minimal impact of UVB on the vitamin D intake-25(OH)D dose-response, and thus the calculated vitamin $\mathrm{D}_{3}$ intake requirements to achieve serum $25(\mathrm{OH}) \mathrm{D}$ thresholds, were included. EFSA in their recent vitamin D DRV analyses defined a period of assumed minimal endogenous vitamin $\mathrm{D}$ synthesis at latitudes $\geq 40^{\circ} \mathrm{N}$ (covering much of Europe) as October through April [7]. The IOM and NNR selected RCTs performed in northern latitudes $>49.5 / 50^{\circ} \mathrm{N}$ in Europe during winter-time as the dataset upon which to explore the vitamin D dose response relationship and establish their DRI $[4,8]$. Thus, we only included data from an RCT if it took place at a latitude greater than at least $40^{\circ} \mathrm{N}$ and entirely within the window of October and April, or had an intermediate sampling point within this winter period and of at least 6 weeks of vitamin D supplementation.

(5) The study duration needed to be at least 6 weeks as serum $25(\mathrm{OH}) \mathrm{D}$ concentrations in adult and elderly subjects only reach equilibrium after 6-8 weeks of vitamin D supplementation [42]. Studies of a duration less than 6 weeks were excluded.

(6) Assessment of vitamin D intakes, on which to base the dose-response calculations, was based on food frequency questionnaire (FFQ), dietary history, 24-hour recall for $\geq 3 \mathrm{~d}$, or a food record or diary for $\geq 3 \mathrm{~d}$, as per [35]. We used 'total vitamin D intake', which is the total vitamin D intake from the diet (including personal vitamin D supplements, where permitted within a RCT) as well as that from any supplemental vitamin D dose provided in the RCT $[43,44]$. The use of total vitamin D intake to derive DRV has been 

prioritized by expert agencies and bodies [4,7-9]. Thus, RCTs that had not assessed habitual vitamin D intake in study participants were excluded.

\section{Identification of studies: Information sources and search strategy}

During May-July 2018, electronic searches were performed in the following three online databases (PubMed, Ovid Medline and Embase) as well as three trial registries

(ClinicalTrials.gov, Cochrane Central Register of Controlled Trials (CENTRAL), and the International Standard Randomized Controlled Trials Number (ISRCTN) registry) from inception to July $31^{\text {st }} 2018$ (date of the final screen) using structured electronic search strategies which accounted for the inclusion/exclusion criteria outlined above. The search strategies were based closely on that used by us previously for identification of vitamin D RCTs that could inform establishment of dietary requirements [30,31], and an exemplar search strategy specifically adapted for PubMed is shown in Supplemental Table 2 in 'Online Resource'. The methods used in the present systematic review follow the PRISMA statement [45].

\section{Study selection and inclusion}

Study selection was independently conducted by two pre-specified investigators (KDC and MEK), first by a screen of the titles and abstracts, followed by a review of the full text of potentially relevant studies. The same two investigators separately determined which RCTs met the eligibility criteria and were included. In addition, the searches were supplemented by searches of review/systematic review articles and reference lists of trial publications as well as from the key international vitamin D DRV reports over the last 9 y [4,7-9]. Duplicates were removed in EndNote (X7.0.1, Clarivate Analytics, Philadelphia, Pennsylvania, United States). Studies that fulfilled the inclusion criteria and were not collected on the basis of the database search were added. Information on the combined number of records identified, abstracts and full-text articles screened, and articles excluded and included in the review are shown in Figure 1. 
236 For each eligible RCT, collaboration was requested and negotiated with the principal

237 investigator [46]. The details of data collection processes, including the requested data items,

238 the checking of the IPD integrity as well as the data protection measures [47] are provided in

239 the Supplemental information on Methods in the 'Online Resource'.

Specification of outcomes and effect measures

242 Serum 25(OH)D concentration was the sole outcome considered in the IPD meta-regression analysis. Likewise, total vitamin D intake was the only predictor considered.

Quality assessment and risk of bias assessment for individual studies

The Jadad scale was used to assess the quality of the included RCTs [48], and an assessment of the risk of bias in these RCTs was performed using the Cochrane Collaboration's tool for assessing risk of bias [49]. Further details on both assessments, including the pre-specified assessors, are provided in the Supplemental information on Methods in the 'Online

250 Resource'.

\section{Statistics}

253 Choice of model

254 A one-stage IPD meta-analysis was carried out [50,51]. Initially, both linear and non-linear regression models for describing the relationship between serum $25(\mathrm{OH}) \mathrm{D}$ and total vitamin $\mathrm{D}_{3}$ intake were fitted [4,28,31] and, based on model diagnostics (residual and QQ plots), results from the most appropriate model were reported. When assuming a linear trend, the one-stage IPD meta-analysis corresponded to fitting a linear regression model with vitamin D intake as the fixed effect and study-specific random intercept and slope effects. When assuming a non-linear trend, the one-stage IPD meta-analysis was carried out by fitting a linear regression model with logarithm-transformed vitamin D intakes and serum $25(\mathrm{OH}) \mathrm{D}$ concentrations, corresponding to a non-linear power model on the original scales; this model provided an operational and reasonable approximation to the exponential models previously 
264

265

266

267

268

269

270

271

272

273

274

275

276

277

278

279

280

281

282

283

284

285

286

287

288

289

290

291

used (as no levelling off at high intakes was observed). Both models without covariate adjustment and models including adjustment for baseline serum $25(\mathrm{OH}) \mathrm{D}$ concentrations, which were also logarithm-transformed in cases where the outcome was logarithmtransformed, age, and BMI were fitted. These were pre-specified covariates commonly used in this type of modelling exercise [7,28]. In sensitivity analyses we also carried out the adjusted analyses replacing BMI by body weight and $z$-scores for body weight or BMI (one at a time). Child age- and sex-specific weight and BMI standard deviation scores ( $z$-scores) were generated using LMS growth software and the UK-WHO 0 to 4-year and UK 4 to 20year growth reference data [52]. Likewise, additional adjustments for methods of vitamin D intake estimation or serum $25(\mathrm{OH}) \mathrm{D}$ measurement were also performed. All models included study-specific random intercepts, implying that linear mixed models were fitted (using restricted maximum likelihood estimation). Intake and covariate adjustment (if included) constituted the fixed effects in the models. The model which adjusted for baseline $25(\mathrm{OH}) \mathrm{D}$, age and BMI will be referred to as the 'adjusted model' throughout the remainder of the paper, and where a model used alternate or additional adjustments these will be highlighted.

To inform safety considerations around each of the various vitamin D intake requirement estimates generated from the present IPD analysis, these were compared to the ULs for vitamin D from children (50-75 $\mu \mathrm{g} / \mathrm{d}$, depending on age group and agency) and adults (100 $\mu \mathrm{g} / \mathrm{d})[4,36]$. In addition, the present unadjusted and adjusted models were used to predict the upper $97.5^{\text {th }}$ percentile of serum $25(\mathrm{OH}) \mathrm{D}$ concentration achieved. While the serum $25(\mathrm{OH}) \mathrm{D}$ concentration representing the vitamin D toxicity threshold in humans is not readily defined [4], EFSA recently concluded that a serum 25(OH)D concentration of $200 \mathrm{nmol} / \mathrm{L}$ or below is unlikely to pose a risk of adverse health outcomes in healthy infants [53], a sensitive group within the population. The IOM, in setting their ULs for vitamin D, also considered if the intakes were likely to lead to serum $25(\mathrm{OH}) \mathrm{D}$ concentration in excess of approximately 125 to $150 \mathrm{nmol} / \mathrm{L}$, which they considered might be of concern based on some observed Ushaped or reverse-J-shaped relationships between serum $25(\mathrm{OH}) \mathrm{D}$ and mortality as well as 
292 other health outcomes [4]. However, EFSA considered that studies reporting on an

293 association between $25(\mathrm{OH}) \mathrm{D}$ concentration and all-cause mortality or cancer were

294 inconsistent and they did not raise this concern [7,36]. Thus, we benchmarked the upper

$29597.5^{\text {th }}$ percentile of serum $25(\mathrm{OH}) \mathrm{D}$ concentrations against serum $25(\mathrm{OH}) \mathrm{D}$ concentrations of 296150 and $200 \mathrm{nmol} / \mathrm{L}$.

297

298 Derivation of vitamin D DRV estimates

299 Lower boundaries of the prediction intervals of the fitted (mean) regression line,

300 corresponding to vitamin D intakes needed to maintain 50, 90, 95, and $97.5 \%$ of the

301 participants above serum $25(\mathrm{OH}) \mathrm{D}$ thresholds of 25,30 , and $50 \mathrm{nmol} / \mathrm{L}$ (where appropriate

302 and feasible) were estimated by means of inverse regression. While SACN's Reference

303 Nutrient Intake (RNI) [9], NNR's Recommended Intake (RI) [8] and IOM's Recommended

304 Dietary Allowance (RDA) [4] are all intended to meet the requirements of $97.5 \%$ of the

305 individuals in the population, EFSA's Adequate Intake (AI) is intended as an intake at which

306 most of the population will achieve the target serum 25(OH)D concentration [7]. Thus, the

307 AI may not cover $97.5 \%$, but $95 \%$ or some other majority percentage. Standard errors and

$30895 \%$ confidence intervals on these estimated lower boundaries were obtained using a

309 parametric bootstrap procedure with 1000 replications, as described previously [28]. In order

310 to achieve comparable fitted regression lines for unadjusted and adjusted model fits, we fixed

311 covariates at their overall mean value (except for intake) in adjusted models.

\section{$313 \quad$ Leave-one-out sensitivity analysis}

314 To assess if there were any overly influential RCTs, the derivation of vitamin D DRV

315 estimates (as described above) based on an unadjusted model based on data from all RCTs

316 was repeated leaving out one RCT at a time. Absolute and relative changes in estimates as

317 compared to the full analysis were reported. 
320 A number of specific subgroups had been considered previously $[4,7,28]$. Therefore we also

321 carried out these subgroup analyses. Specifically, we fitted separate models for subgroups of

322 children ( $<18$ years) and adults $(\geq 18$ years) and for subgroups of participants whose baseline

323 serum $25(\mathrm{OH}) \mathrm{D}$ was $<$ or $\geq 50 \mathrm{nmol} / \mathrm{L}$. We also fitted separate models for the subgroup of

324 RCTs of children and adults which were $\geq 50^{\circ} \mathrm{N}$; only models including adjustment for

325 baseline serum 25(OH)D level, age, and BMI were fitted. Furthermore, we fitted separate

326 models for the subgroup of RCTs of adults which provided vitamin D at a dose $\leq 30 \mu \mathrm{g} / \mathrm{day}$,

327 above which the rise in serum $25(\mathrm{OH}) \mathrm{D}$ to additional vitamin $\mathrm{D}$ is less steep [31]. We also

328 fitted separate models for a subgroup consisting of adult participants with BMI $<25 \mathrm{~kg} / \mathrm{m}^{2}$.

329 Lastly, we did subgroup analysis for RCTs where compliance data were available and for

330 participants showing compliance above $80 \%$, and separately above $95 \%$. The subgroup

331 analyses were pre-specified rendering testing for interaction unnecessary.

Estimation of rate constants for included RCTs

334 It has been suggested that the bioavailability of vitamin D from food could potentially be influenced by the complexity of the food matrix [54]. However, data from the limited number of RCTs which compared vitamin $\mathrm{D}_{3}$-fortified foods (regular and low-fat cheese, orange juice, various breads) with vitamin $\mathrm{D}_{3}$ supplements demonstrate equal bioavailability [55-58]. Use of the 'rate constant' (i.e. the change in $25(\mathrm{OH}) \mathrm{D}$ in $\mathrm{nmol} / \mathrm{L}$ per $\mu \mathrm{g}$ vitamin $\mathrm{D}$ administered [59]) would allow a comparison of vitamin D status improvement per dose of vitamin D from fortified foods and supplements across RCTs among individuals of different ages within the present IPD and equivalent winter-based RCTs with vitamin D supplements included in the IOM's DRI exercise [4], respectively. Rate constants were calculated as described by Whiting et al. [59], namely, for both the control (placebo) group and the treatment group(s), the net change from baseline to endpoint $25(\mathrm{OH}) \mathrm{D}$ determined by subtraction. The rise (or fall) in $25(\mathrm{OH}) \mathrm{D}$ of the control group is subtracted (or added) to the net change of $25(\mathrm{OH}) \mathrm{D}$ in the treatment group $(\mathrm{s})$. The resulting $\mathrm{nmol} / \mathrm{L}$ is divided by the dose

347 (in $\mu \mathrm{g}$ ) of vitamin $\mathrm{D}_{3}$ administered [59]. 
Statistical software

350 All analyses were conducted using R version 3.6.2 (R Core Team, Vienna, Austria) and the R extension packages "boot" for bootstrapping; "medrc", "lme4" [60] and "nlme" [61] for fitting linear mixed models. The R code for fitting linear and nonlinear models is presented elsewhere [34].

\section{RESULTS}

\section{Study selection and IPD obtained}

Our search identified 644 unique articles, the titles and abstracts of which were screened and ultimately 86 full-text articles were assessed for eligibility. Of these 86 articles, 11 studies [55,62-71] fulfilled the eligibility criteria (Fig 1). IPD were sought and obtained for all 11 studies, with a total of 1429 randomized participants that fulfilled the eligibility criteria. A number of the studies had additional participants that did not meet the eligibility criteria (e.g., were dark-skinned (in 5 RCTs), sampled outside the specified winter period (in 1 RCT), below the age threshold of 24 months (in 1 RCT), or had missing data on a required variable (in 4 RCTs)), and the data on these additional participants were not included in the present analysis.

\section{Study and participant characteristics}

Table 1 shows the characteristics of the 11 eligible studies and their participants. The RCTs were conducted in 8 countries within North America and Europe. Seven studies were conducted in adults, 3 in children, and 1 in both age-groups. Three studies were conducted in adult females only, the rest were conducted in studies with a mixture of males and females.

372 Among the 11 RCTs, mean baseline serum 25(OH)D concentrations ranged from 45.9 to 75.0

$373 \mathrm{nmol} / \mathrm{L} ; 2$ studies had mean baseline concentrations in the range of 40-49.9 nmol/L, 4 studies 374 each were within the range of 50-59.9 nmol/L and 60-69.9 nmol/L, respectively, and 1 study 
375 had a mean baseline concentration $>70 \mathrm{nmol} / \mathrm{L}$ (Table 1). Five of the $11 \mathrm{RCTs}$ had a

376 requirement that participants would not travel to a sunny locale and/or use tanning beds

377 during the study. Four and 7 RCTs were conducted within latitude bands of 40 to $49.9^{\circ} \mathrm{N}$ and

37850 to $63^{\circ} \mathrm{N}$, respectively. A range of assay types were used to measure serum $25(\mathrm{OH}) \mathrm{D}$,

379 including RIA (in 3 studies), LC-MS/MS (in 5 studies) and one study each used HPLC,

380 ELISA, or chemiluminescence immunoassay (Table 1).

381

382 All RCTs administered vitamin D-fortified/enhanced/enriched food(s) to participants in the

383 intervention arms: given daily (10 RCTs) or weekly (1 RCT). The daily (or daily equivalent)

384 dose of vitamin D provided by consumption of the assigned amount/serving size of the

385 vitamin D-fortified/enhanced/enriched food(s) ranged from 3.5 to $100 \mu \mathrm{g} / \mathrm{d}$ : 5 studies used

$386 \leq 10 \mu \mathrm{g} / \mathrm{d}, 1$ study used 10 and $15 \mu \mathrm{g} / \mathrm{d}, 4$ studies used $\geq 12-30 \mu \mathrm{g} / \mathrm{d}$, and 1 study used 100

$387 \mu \mathrm{g} / \mathrm{d}$ equivalent (Table 1). Six studies used dairy-based foods (of which 5 used a single

388 source (cheese or a cow's milk-based beverage) and 1 used yoghurt and cheese), 1 RCT each

389 used bread; eggs; orange juice or biscuits; or milk plus bread; or a combination of 4 foods

390 (vitamin D-fortified low-fat cheese, yoghurt, eggs and crisp bread) (Table 1). The RCTs had

391 a variety of consumption patterns for the study foods ranging from being consumed once per

392 week, once per day, to participants being allowed to freely plan how they distributed the

393 provided foods over a day or week as long as they consumed the designated amount (data not

394 shown). Study duration ranged from 8 weeks to 6 months. A range of dietary instruments

395 were used to assess vitamin D intake, including 72-h detailed dietary intake report (1 study),

396 4-day diet diary (1 study), 3-day diet records (2 studies), and semi-quantitative FFQ (7

397 studies; with 5 reporting their FFQ as validated for habitual vitamin D intake).

398

399

400 Study quality of included RCTs

401 All 11 studies achieved a Jadad score of 3 (18\% and 55\% with scores of 4 and 5,

402 respectively). In terms of contributing to these scores, method of randomization was reported 
403 in nine studies. Two studies were reported as blinded, but methods for blinding were unclear

404 based on the information presented within the papers, upon which the Jadad scores are

405 adjudged (this information was attained after the fact from the PIs for use in the Risk of bias

406 assessment, see Supplemental information on Methods in the 'Online Resource'). Ten of the

40711 RCTs reported analytical verification of the vitamin D content of the vitamin D-

408 fortified/enhanced/enriched food(s). All 11 studies reported data on dropouts. There was a

409 relatively low percentage of participant dropouts (0-18.5\% within a study arm) and only one

410 study had a dropout rate of $>15 \%$. It should be noted that the Jadad scale does not assess

411 compliance, which is an important factor in food-based interventions. Compliance rates were

412 reported in 9 studies (range of means: 79-98\% with 7 RCTs $>90 \%$ ), one study did not assess

413 compliance, and another study failed to report on compliance rate even though it was

414 assessed.

415

416 Risk of bias within studies

417 The summary assessments of risk of bias across domains and across the 11 RCTs are shown

418 in Supplemental Table 3 in 'Online Resource'. The majority of RCTs had either a low or

419 unclear risk of selection bias (low risk of random sequence generation and allocation

420 concealment for 9 and 8 RCTs, respectively, and the remainder had unclear risk). In relation

421 to performance and detection bias, a majority of RCTs (n 9-10) had low risk of bias for

422 blinding of participants, personnel and of outcome assessment, with 1-2 RCTs having unclear

423 risk in these domains. In relation to attrition bias, risk of bias in relation to incomplete

424 outcome data was low for 10 RCTs and unclear for the remaining study. Risk of bias for

425 selective reporting was low in all 11 RCTs. Overall, most of the information used in the

426 present meta-regression analysis is from studies at low, or to a lesser extent, unclear risk of

427 bias.

Rate constants of included vitamin D-fortified food RCTs versus those of vitamin D supplement RCTs

430 The rate constants (nmol/L per $\mu$ g additional vitamin $\mathrm{D}$ intake) for the vitamin $\mathrm{D}$-fortified 
431 food RCTs [55,62-71] and appropriate vitamin D supplement RCTs as part of the IOM DRI 432 exercise [4] plus a few published since [72-75], stratified by age-group and latitude band in 433 which they were conducted, are shown in Supplemental Table 4. The median rate constant 434 for all RCTs, irrespective of age, in the present IPD (excluding one RCT with the negative 435 rate constant in older adults, see below) and the updated IOM collection were similar at 1.7 436 and 1.6, respectively. The median rate constant from the collection of RCTs in children (at $\left.437 \geq 50^{\circ} \mathrm{N}\right)$ in the present IPD was similar (1.9) to that of the updated IOM RCT collection (2.1). 438 For adults, the median rate constants were 2.6 and 1.9 for $\geq 50^{\circ} \mathrm{N}$ RCTs in the IPD and IOM 439 analyses, respectively; and 0.8 and 0.9 for $40-49.5^{\circ} \mathrm{N}$ RCTs in the IPD and IOM analyses,

440 respectively. There was only one RCT of older adults (>60 years) in the present IPD

441 collection and that showed a negative rate constant (i.e., no response) [62] compared to the

$4421.3 \mathrm{nmol} / \mathrm{L}$ per $\mu \mathrm{g}$ additional vitamin D intake for the one RCT in the IOM collection [42].

443 In the present IPD, the median rate constant of RCTs in children (at $\geq 50^{\circ} \mathrm{N}$ ) was lower (1.9)

444 than that of RCTs in adults (2.6). In the updated IOM collection of RCTs, the median rate 445 constant of RCTs in children (at $\geq 50^{\circ} \mathrm{N}$ ) was similar (2.1) to that of RCTs in adults (1.9).

447 The IPD meta-analysis model and vitamin D DRV estimates based on the 1-stage IPD meta448 analyses, including subgroup analyses

449 Following an assessment of the 1-stage IPD meta-analysis models, a log-log model was 450 judged to be the best fit. The analyses included an unadjusted model (Figure 2A) as per IOM, 451 NNR and SACN $[4,8,9]$, as well as a model adjusted for covariates (mean values for baseline 452 25(OH)D, age and BMI) (Figure 2B) similar to EFSA which adjusted for baseline 25(OH)D and other covariates [7]. Based on these 1-stage IPD meta-analysis models, the estimated vitamin D intakes needed to maintain $97.5 \%$ of individuals at latitudes $\geq 40^{\circ} \mathrm{N}$ and $\geq 50^{\circ} \mathrm{N}$ at pre-determined serum $25(\mathrm{OH}) \mathrm{D}$ thresholds as per agencies [4,7-9], assuming minimal UVB exposure, are shown in Table 2. As the increase in vitamin D intake estimates moving from the $90^{\text {th }}$ to the $97.5^{\text {th }}$ percentile of requirements were very large, especially at the $50 \mathrm{nmol} / \mathrm{L}$ serum $25(\mathrm{OH}) \mathrm{D}$ threshold, it is important to also emphasize intake estimates at the $90^{\text {th }}$ and 
$95^{\text {th }}$ percentiles, as shown in Table 3.

Using the UK SACN 25(OH)D cut-off of $\geq 25 \mathrm{nmol} / \mathrm{L}$ [9], we estimated the vitamin D intake needed to maintain $97.5 \%$ of individuals above this threshold to be $5.9 \mu \mathrm{g} / \mathrm{d}$ based on the unadjusted model of RCTs $\geq 40^{\circ} \mathrm{N}$; this decreased to $2.0 \mu \mathrm{g} / \mathrm{d}$ with adjustment for covariates (Table 2). The IOM, NNR and EFSA used $30 \mathrm{nmol} / \mathrm{L}$ to indicate an increased risk of vitamin D deficiency $[4,7,8]$, but they did not derive a vitamin $\mathrm{D}$ intake for this threshold. We estimated a vitamin D intake of $12.2 \mu \mathrm{g} / \mathrm{d}$ to maintain $97.5 \%$ of individuals $\geq 30 \mathrm{nmol} / \mathrm{L}$ using the unadjusted model and $4.5 \mu \mathrm{g} / \mathrm{d}$ using the adjusted model. The vitamin D intake estimate allowing $97.5 \%$ of individuals to maintain serum $25(\mathrm{OH}) \mathrm{D} \geq 50 \mathrm{nmol} / \mathrm{L}$ (the threshold of adequacy as selected by IOM [4], NNR [8] and EFSA [7]) was $92.3 \mu \mathrm{g} / \mathrm{d}$ and $43.6 \mu \mathrm{g} / \mathrm{d}$ using the unadjusted and adjusted models, respectively (Table 2). The vitamin D intake estimate required to maintain $90 \%$ and $95 \%$ of individuals $\geq 50 \mathrm{nmol} / \mathrm{L}$ was $33.4 \mu \mathrm{g} / \mathrm{d}$ and $57.5 \mu \mathrm{g} / \mathrm{d}$, respectively using the adjusted model, and $17.0 \mu \mathrm{g} / \mathrm{d}$ and $28.1 \mu \mathrm{g} / \mathrm{d}$, respectively using the unadjusted model (Table 3). Excluding the Wagner et al. RCT [55] data (which provided additional vitamin D as a once-weekly dose of $700 \mu \mathrm{g}$ ) from the IPD analysis led to slightly higher DRV estimates than the full RCT dataset (range: $0.1-0.5 \mu \mathrm{g} / \mathrm{d}$ higher at the 25 and 30 $\mathrm{nmol} / \mathrm{L}$ thresholds and 2.9-4.3 $\mu \mathrm{g} / \mathrm{d}$ higher at the $50 \mathrm{nmol} / \mathrm{L}$ threshold, depending on the model) (data not shown).

By age-group, the intake estimates allowing $90 \%, 95 \%$ and $97.5 \%$ of children $(2-17.9$ y) to maintain serum $25(\mathrm{OH}) \mathrm{D} \geq 50 \mathrm{nmol} / \mathrm{L}$ were two to five times lower than those of adults $(\geq 18$ years), depending on whether they were derived from the unadjusted or adjusted model (Table 3). When the 25 or $30 \mathrm{nmol} / \mathrm{L}$ serum 25(OH)D thresholds were applied, the intake estimates at the $90^{\text {th }}, 95^{\text {th }}$ and $97.5^{\text {th }}$ percentiles were also lower for children compared to adults from the unadjusted model only (Table 3). For those studies that reported compliance, there was no statistical difference $(P=0.11)$ in median compliance between adults and children (at 98.2\% and 95.6\%, respectively). 
485 The median requirement (i.e. EAR) at the $50 \mathrm{nmol} / \mathrm{L}$ serum $25(\mathrm{OH}) \mathrm{D}$ threshold was similar

486 for adults and children (5.0 and $5.1 \mu \mathrm{g} / \mathrm{d}$, respectively) based on the unadjusted model, but

487 was higher for children than adults (3.8 versus $2.6 \mu \mathrm{g} / \mathrm{d}$, respectively) based on the adjusted

488 model (Table 3). Using a model which adjusted for baseline 25(OH)D only (not including

$489 \mathrm{BMI}$ and age as additional covariates) showed that the EAR at $50 \mathrm{nmol} / \mathrm{L}$ was 3.6 and 2.5

$490 \mu \mathrm{g} / \mathrm{d}$ for children and adults, respectively (data not shown).

491 Seven of the 11 RCTs from which the IPD were drawn were conducted $\geq 50^{\circ} \mathrm{N}$, a cut-off used

492 by the IOM [4] and NNR [8], as well as being consistent with the three RCTs used by the

493 SACN [9]. Results of the subgroup analysis of data from these 7 RCTs in unadjusted and

494 adjusted models conducted under the same conditions were broadly similar to the equivalent

495 estimates from the full RCT dataset (i.e., $40-63^{\circ} \mathrm{N}$ ), for all ages and for adults or children only

496 (Table 2 for the $97.5^{\text {th }}$ percentile, data not shown for the $90^{\text {th }}$ and $95^{\text {th }}$ percentiles).

497

498 Sensitivity analyses

499 A leave-one-out sensitivity analysis showed modest changes (maximum 17.6\%, 16.2 $\mu \mathrm{g} / \mathrm{d}$ )

500 and there were no overly influential RCTs (Supplemental Table 5 in 'Online Resource').

501 The vitamin D intake requirement estimates at the $97.5^{\text {th }}$ percentile based on regression models adjusted for baseline 25(OH)D alone versus baseline 25(OH)D, age and BMI were almost identical (maximum difference between estimates, $0.4 \mu \mathrm{g} / \mathrm{d}$; data not shown).

504 Changing the anthropometry covariate had a negligible effect on the DRV estimates.

505 Supplemental Table 6 in 'Online Resource' provides the vitamin D intake estimates for $97.5 \%$ to maintain serum $25(\mathrm{OH}) \mathrm{D}$ above the predefined thresholds based on regression models adjusted for baseline $25(\mathrm{OH}) \mathrm{D}$, age and $\mathrm{BMI}$ and substituted by weight, z-scores of weights and z-scores of BMI. Using adult RCT data only, limiting the analysis to those

509 whose BMI was less than $25 \mathrm{~kg} / \mathrm{m}^{2}$ showed that the $97.5^{\text {th }}$ percentile vitamin D estimates at 510 the 25 and $30 \mathrm{nmol} / \mathrm{L}$ thresholds were slightly lower (range $0.3-1.4 \mu \mathrm{g} / \mathrm{d}$ lower, depending on 
511 the model) than those from analysis of all adults. For the $50 \mathrm{nmol} / \mathrm{L}$ threshold, shown in

512 Supplemental Table 7 in 'Online Resource', $97.5^{\text {th }}$ percentile estimates were 5.2 and 14.5

$513 \mu \mathrm{g} / \mathrm{d}$ lower for the adults with BMI $<25$ compared to the full adult dataset, using unadjusted

514 and adjusted models, respectively

515 Baseline serum 25(OH)D had a major effect on estimates. Subgroup analysis, using the

516 unadjusted regression model, showed that the vitamin D intake requirement estimates at the

$51797.5^{\text {th }}$ percentile at each of the three serum $25(\mathrm{OH}) \mathrm{D}$ thresholds were 3 - to 6 -times higher in

518 subjects whose baseline $25(\mathrm{OH}) \mathrm{D}$ concentrations was $<50 \mathrm{nmol} / \mathrm{L}$ compared to those with

519 baseline concentrations $\geq 50 \mathrm{nmol} / \mathrm{L}$. At the 25 and $30 \mathrm{nmol} / \mathrm{L}$ thresholds, the respective

520 RDA estimates $(95 \% \mathrm{CI})$ were $11.8(7.0,19.8) \mu \mathrm{g} / \mathrm{d}$ and $23.4(14.6,37.0) \mu \mathrm{g} / \mathrm{d}$ for those with

521 baseline $25(\mathrm{OH}) \mathrm{D}<50 \mathrm{nmol} / \mathrm{L}$, and $2.1(1.4,3.3) \mu \mathrm{g} / \mathrm{d}$ and $4.8(3.1,7.4) \mu \mathrm{g} / \mathrm{d}$ for those with

522 baseline $25(\mathrm{OH}) \mathrm{D} \geq 50 \mathrm{nmol} / \mathrm{L}$ (data not shown). At the $50 \mathrm{nmol} / \mathrm{L}$ serum $25(\mathrm{OH}) \mathrm{D}$

523 threshold, the respective $90^{\text {th }}, 95^{\text {th }}$ and $97.5^{\text {th }}$ percentile requirement estimates $(95 \% \mathrm{CI})$ were

$524 \quad 63.8(41.2,104.7) \mu \mathrm{g} / \mathrm{d}, 105.0(64.5,179.2) \mu \mathrm{g} / \mathrm{d}$ and $162(94.1,270.9) \mu \mathrm{g} / \mathrm{d}$ for those with

525 baseline $25(\mathrm{OH}) \mathrm{D}<50 \mathrm{nmol} / \mathrm{L}$, and $17.1(11.6,24.8) \mu \mathrm{g} / \mathrm{d}, 29.7(19.7,45.5) \mu \mathrm{g} / \mathrm{d}$ and 47.8

$526(31.3,81.5) \mu \mathrm{g} / \mathrm{d}$ for those with baseline $25(\mathrm{OH}) \mathrm{D} \geq 50 \mathrm{nmol} / \mathrm{L}$ (data not shown).

527 Addition of the method of vitamin D intake assessment as an additional covariate to the

528 model (also adjusted for baseline $25(\mathrm{OH}) \mathrm{D}$, age and BMI) yielded vitamin D estimates at the

$52997.5^{\text {th }}$ percentile that were higher (by $0.7,1.4$ and $10 \mu \mathrm{g} / \mathrm{d}$ at the 25,30 and $50 \mathrm{nmol} / \mathrm{L}$ serum

$53025(\mathrm{OH}) \mathrm{D}$ thresholds, respectively) than those from analysis of all adults, irrespective of

531 intake assessment method (data not shown). In the leave-one-out sensitivity analysis,

532 variability in the range of change in RDA estimates at the $50 \mathrm{nmol} / \mathrm{L}$ serum $25(\mathrm{OH}) \mathrm{D}$

533 threshold on omission of individual RCTs was evident in those which estimated vitamin D

534 intake by FFQ (-17.6\% to $22.2 \%)$ and non-FFQ assessment methods (-16.7\% to $12.8 \%)$

535 (Supplemental Table 4 in 'Online Resource').

536 Likewise, addition of method of serum $25(\mathrm{OH}) \mathrm{D}$ measurement as an additional covariate 
537 within the model yielded $97.5^{\text {th }}$ percentile vitamin D estimates that were higher (by $1.1,2.2$

538 and $16.7 \mu \mathrm{g} / \mathrm{d}$ at the 25,30 and $50 \mathrm{nmol} / \mathrm{L}$ serum $25(\mathrm{OH}) \mathrm{D}$ thresholds, respectively) than

539 those from analysis of all adults, irrespective of $25(\mathrm{OH}) \mathrm{D}$ measurement method (data not

540 shown). In the leave-one-out sensitivity analysis, variability in the range of change in RDA

541 estimates at the $50 \mathrm{nmol} / \mathrm{L}$ serum $25(\mathrm{OH}) \mathrm{D}$ threshold on omission of individual RCTs was

542 evident in those which measured serum $25(\mathrm{OH}) \mathrm{D}$ by chromatographic $(-17.6 \%$ to $22.2 \%)$ and

543 non-chromatographic methods (-16.7\% to 4.7\%) (Supplemental Table 4 in 'Online

544 Resource').

545 Seven of the 11 RCTs from which the IPD were drawn had available individual-level data on 546 compliance of consumption of the intervention food(s). An analysis of the estimates from a 1547 step IPD meta-analysis model using data from this subset of 7 RCTs showed that percentage 548 compliance with the food product had a relatively minor impact on the intake estimates at the

54925 and $30 \mathrm{nmol} / \mathrm{L}$ serum $25(\mathrm{OH}) \mathrm{D}$ thresholds, i.e., estimates being 0 to $0.9 \mu \mathrm{g} / \mathrm{d}$ lower, 550 depending on the intake requirement percentiles $\left(90^{\text {th }}\right.$ to $\left.97.5^{\text {th }}\right)$ and whether $80 \%$ or $95 \%$ compliance threshold (Supplemental Table 8 in 'Online Resource'). At the $50 \mathrm{nmol} / \mathrm{L}$ serum $25(\mathrm{OH}) \mathrm{D}$ threshold, estimates were 2.5 to $10.1 \mu \mathrm{g} / \mathrm{d}$ lower than those from models not accounting for compliance, going from the $90^{\text {th }}$ to $97.5^{\text {th }}$ percentile, depending on whether $80 \%$ or $95 \%$ compliance threshold applied (Supplemental Table 7). The age-group specific differences in estimates in the full dataset from these 7 RCTs were also evident when the dataset excluded subjects with compliance $<80 \%$ or $<95 \%$ (Supplemental Table 7 ). This was also the case when unadjusted models were used (data not shown).

None of the vitamin D intake requirement estimates, derived from the adjusted models, exceeded the age-specific UL for vitamin D (Table 3). Using the intake estimates from the unadjusted models, none of the estimates for children exceeded the minimum specified UL

562 for children $(50 \mu \mathrm{g} / \mathrm{d}[35])$. While the intake estimates covering $90 \%$ or $95 \%$ of adults did not, the $97.5 \%$ estimate for adults did exceed the UL (Table 3). 
564 The projected upper $97.5^{\text {th }}$ percentile serum $25(\mathrm{OH}) \mathrm{D}$ concentrations achieved at vitamin D

565 intake requirement estimates, derived from the unadjusted and adjusted models, are shown in

566 Table 4. None of the vitamin D intake requirement estimates at the 25 and $30 \mathrm{nmol} / \mathrm{L}$ serum

$56725(\mathrm{OH}) \mathrm{D}$ thresholds, from either the unadjusted or adjusted models, and whether covering

56890,95 or 97.5 percent of individuals, led to predicted upper $97.5^{\text {th }}$ percentiles of serum

$56925(\mathrm{OH}) \mathrm{D}$ concentrations exceeding $150 \mathrm{nmol} / \mathrm{L}$ (maximum of $132 \mathrm{nmol} / \mathrm{L}$ at $12 \mu \mathrm{g} / \mathrm{d}$ intake,

570 corresponding to the intake needed to maintain $97.5 \%$ of individuals with serum $25(\mathrm{OH}) \mathrm{D}$

$571 \geq 30 \mathrm{nmol} / \mathrm{L}$ ). Using the vitamin $\mathrm{D}$ intake requirement estimates at the $50 \mathrm{nmol} / \mathrm{L}$ threshold,

572 and based on the adjusted model, none of the three predicted upper $97.5^{\text {th }}$ percentiles of

573 serum 25(OH)D concentrations exceeded $200 \mathrm{nmol} / \mathrm{L}$; with the vitamin D intakes covering

$57495 \%$ and $97.5 \%$ of individuals leading to $97.5^{\text {th }}$ percentile serum $25(\mathrm{OH}) \mathrm{D}$ of 155 and 171

$575 \mathrm{nmol} / \mathrm{L}$, respectively (Table 4). Using on the unadjusted model, all three predicted upper

$57697.5^{\text {th }}$ percentiles of serum $25(\mathrm{OH}) \mathrm{D}$ concentrations exceeded $150 \mathrm{nmol} / \mathrm{L}$, and the vitamin D

577 intake to cover the needs of $97.5 \%$ of individuals $(92.3 \mu \mathrm{g} / \mathrm{d})$ at $50 \mathrm{nmol} / \mathrm{L}$ threshold yielded

578 a predicted upper $97.5^{\text {th }}$ percentile serum $25(\mathrm{OH}) \mathrm{D}$ concentration of $220 \mathrm{nmol} / \mathrm{L}$ (Table 4).

579 The vitamin D intakes corresponding to the EAR $\left(50^{\text {th }}\right.$ percentile $)$ at the $50 \mathrm{nmol} / \mathrm{L}$ threshold

580 yielded a predicted upper $97.5^{\text {th }}$ percentile serum $25(\mathrm{OH}) \mathrm{D}$ concentration of 105 and 93

$581 \mathrm{nmol} / \mathrm{L}$, based on unadjusted and adjusted models, respectively (data not shown). 
583

584

585

586

587

588

589

590

591

592

593

594

595

596

597

598

599

600

601

602

603

604

605

606

607

608

609

610

611

612

\section{Discussion}

Since 2010, most expert agencies tasked with updating their vitamin D DRV have employed a standard meta-analysis approach based on aggregate data from RCTs, mostly with vitamin D supplements $[4,7,8]$. The present IPD analyses, based on pooled individual data from 11 winter-based RCTs using vitamin D-fortified foods provides new estimates for the vitamin D intakes needed to maintain individual winter-time serum $25(\mathrm{OH}) \mathrm{D}$ concentrations above commonly used thresholds. The approach used for data analysis, including the model and adjustments included, had a profound impact on the DRV estimates generated. For example, using data from RCTs conducted $\geq 50^{\circ} \mathrm{N}$ in an unadjusted curvilinear model, we estimated that the vitamin D intakes required to maintain $97.5 \%$ of serum $25(\mathrm{OH}) \mathrm{D}$ concentrations $\geq 25$ $\mathrm{nmol} / \mathrm{L}[9]$ and $\geq 30 \mathrm{nmol} / \mathrm{L}$ were $6 \mu \mathrm{g} / \mathrm{d}$ and $12 \mu \mathrm{g} / \mathrm{d}$, respectively. Adjustment for mean values of baseline $25(\mathrm{OH}) \mathrm{D}$, age and BMI reduced these estimates to 2.5 and $5.1 \mu \mathrm{g} / \mathrm{d}$, respectively. Staying with studies $\geq 50^{\circ} \mathrm{N}$ and switching to the $50 \mathrm{nmol} / \mathrm{L}$ threshold $[4,8]$, the vitamin D intake required to maintain $90 \%, 95 \%$ and $97.5 \%$ of serum $25(\mathrm{OH}) \mathrm{D}$ concentrations $\geq 50 \mathrm{nmol} / \mathrm{L}$ was estimated to be 30,49 and $75 \mu \mathrm{g} / \mathrm{d}$, respectively. Adjustment for mean baseline $25(\mathrm{OH}) \mathrm{D}$, age and BMI derived lower estimates of 16.1 and $25.5 \mu \mathrm{g} / \mathrm{d}$ at the $90^{\text {th }}$ and $95^{\text {th }}$ percentiles and $38 \mu \mathrm{g} / \mathrm{d}$ at the $97.5^{\text {th }}$ percentile. Emphasis on the estimates at the $90^{\text {th }}$ and $95^{\text {th }}$ percentiles in the present work is of importance as the estimates at the $97.5^{\text {th }}$ were very high and need to considered with caution.

The striking differences between the estimates at the $90^{\text {th }}$ and $95^{\text {th }}$, as well as the $97.5^{\text {th }}$, percentiles for adults at the $50 \mathrm{nmol} / \mathrm{L}$ threshold from the present food trial-based and previous supplement trial-based IPD analyses [28] and the recommended $10 \mu \mathrm{g} / \mathrm{d}$ by NNR [8] and $15 \mu \mathrm{g} / \mathrm{d}$ by IOM (for those aged 1-70 y) [4] and EFSA [7] relate to the fact that the standard meta-analysis, as applied by these agencies, is not able to add the two required standard deviations to the median serum $25(\mathrm{OH}) \mathrm{D}$ response to cover the $97.5^{\text {th }}$ percentile of individuals, as information on the between-individual variability is not accessible [29]. The IPD approach is highly relevant and applicable in this regard as between-participant variability is crucial for estimating individual-based DRV, such as the RDA, RNI, RI, and the EU's Population Reference Intake (PRI) [29]. SACN's RNI of $10 \mu \mathrm{g} / \mathrm{d}$ was based on 
613 regression analysis of individual data, but only from one RCT each in children, adults and

614 older adults [9], unlike the present IPD which used pooled individual data from 11 RCTs.

615

616 The present vitamin D intake estimates at the $90^{\text {th }}, 95^{\text {th }}$ and $97.5^{\text {th }}$ percentiles using all three 617 serum $25(\mathrm{OH}) \mathrm{D}$ thresholds $(25,30$ and $50 \mathrm{nmol} / \mathrm{L})$ from the unadjusted models were 2- to 5-

618 fold higher for adults than for children. Likewise, the $90^{\text {th }}, 95^{\text {th }}$ and $97.5^{\text {th }}$ percentile

619 estimates at the $50 \mathrm{nmol} / \mathrm{L}$ serum $25(\mathrm{OH}) \mathrm{D}$ threshold from the adjusted model were $\sim 2$-times

620 higher for adults than children; even though estimates were broadly similar for adults and

621 children at the two lower thresholds. In contrast, IOM, NNR and EFSA, who combined data

622 from RCTs in children and in adults (up to 60 years in the case of NNR) in their respective

623 analyses [4,7,8], established the same vitamin D DRV for children and adults. SACN used

624 data from a RCT in 11-year-old girls as well as one RCT each in adults and older adults [9].

625 Brett et al. [26] in a subgroup analysis within their recent meta-analysis based on aggregate

626 data of vitamin D RCTs in children aged 2-18 y, reported the mean change in serum

$62725(\mathrm{OH}) \mathrm{D}$ per $2.5 \mu \mathrm{g}$ vitamin $\mathrm{D} / \mathrm{d}$ supplied as fortified food $(9.3 \mathrm{nmol} / \mathrm{L})$, and highlighted that

628 this was about 3-times higher than that reported in either of the two equivalent meta-analyses

629 of adults $(\sim 3 \mathrm{nmol} / \mathrm{L} ;[21,22])$. Lower requirements for vitamin $\mathrm{D}$ in children have been

630 suggested to be possibly linked to body size [26,72,76], with children being, on average,

631 smaller than adults and their tissue stores taking up a smaller amount of vitamin D from the

632 circulation [26]. A greater volumetric dilution of ingested vitamin D within adults compared

633 to children, is akin to that suggested to explain the lower vitamin D status among obese

634 versus healthy weight adults [77]. The 2-fold difference in vitamin D requirement estimates

635 at the $50 \mathrm{nmol} / \mathrm{L}$ serum $25(\mathrm{OH}) \mathrm{D}$ threshold between children and adults in the present IPD

636 remained even when body weight or z-scores for weight or BMI were substituted for BMI as

637 a covariate within the analyses. There may be other factors contributing to the lower

638 variability in serum $25(\mathrm{OH}) \mathrm{D}$ response to a specific vitamin D intake in children compared to

639 that seen in adults. There were no significant differences in compliance between children and

640 adults for those RCTs which had data available, suggesting this was likely not a key

641 contributory factor.

642

643 That the extra vitamin D supplied in the RCTs included in the present IPD was by means of

644 food vehicles is both timely and important as much of the analysis to-date has focussed on 
645 data from vitamin D supplement RCTs [4,7-9]. Only EFSA included limited data from RCTs 646 with vitamin D-fortified foods in their analyses (e.g., 18 RCT arms out of total of 83) [7]. It is 647 worth considering that estimates arising from food-based studies may be highly relevant as 648 the WHO-FAO [20] and others $[3,14,19,25,78]$ have highlighted the advantages of a fortified 649 food-based approach over supplements as a more effective public health strategy for 650 increasing vitamin D in the food chain. While acknowledging the WHO-FAO's suggestion that increasing dietary diversity may be the most preferred way of addressing micronutrient malnutrition [20], this is not feasible for vitamin D, because there are very few naturally rich food sources [14]. However, increasing diversity in the context of types of foods fortified with vitamin D has been emphasised [14,21,23,25,78], as a wider suite of foods, in addition to milk/other dairy-based products (such as cheese and yoghurts), has the potential to increase vitamin D intakes in the population, especially among non- or low-dairy consumers. In this regard, the overall findings of this IPD highlight how vitamin D fortification of breads, biscuits, orange juice, and eggs, as well as milk/dairy products, alone or in some combination(s), can increase vitamin D status in children and adults.

661 While, the response of serum $25(\mathrm{OH}) \mathrm{D}$ to increased vitamin D intake from fortified cheese 662 (i.e., the rate constant) was unexplainably low in one RCT [62], the rate constants from the other 10 RCTs with vitamin D-fortified foods and from RCTs with vitamin D supplements were comparable, suggesting similar bioavailability across a range of food products. The present IPD's finding that $12 \mu \mathrm{g} / \mathrm{d}$ of vitamin D, supplied by fortified foods together with habitual intake, can prevent wintertime vitamin D deficiency (serum $25(\mathrm{OH}) \mathrm{D}<30 \mathrm{nmol} / \mathrm{L}$ ) in the vast majority of individuals is broadly in line with nationally representative data from Finland, who have one of the most progressive vitamin D food fortification programmes in Europe. For example, the representative National FINDIET 2012 survey in Finland has shown that the mean daily vitamin D intake has increased from 3 and $5 \mu \mathrm{g} /$ day for women and men, respectively, in 2002 (prior to instigation of food fortification a year later) to 18 and $17 \mu \mathrm{g} /$ day for women and men, respectively, in 2012 [79]. Such increases in vitamin D intakes have been mirrored by notable improvements in status over the same period. Data

674 from the Finnish Health surveys in 2000 and 2011 show that the mean standardized serum $25(\mathrm{OH}) \mathrm{D}$ increased from $48 \mathrm{nmol} / \mathrm{L}$ to $65 \mathrm{nmol} / \mathrm{L}$, and prevalence of serum $25(\mathrm{OH}) \mathrm{D}<30$ nmol/L decreased from $13 \%$ to $<1 \%$ [80]. From a safety perspective, the present IPD 
677 suggested a vitamin intake of $12 \mu \mathrm{g} /$ day yielded an upper $97.5^{\text {th }}$ percentile serum $25(\mathrm{OH}) \mathrm{D}$ of

$678132 \mathrm{nmol} / \mathrm{L}$ and the 2011 Finnish Health survey only reported $0.2 \%$ of its 4,051participants

679 with serum $25(\mathrm{OH}) \mathrm{D}>125 \mathrm{nmol} / \mathrm{L}$ [80].

680

681 Limitations of the present IPD analysis are exemplified in the variation in the $97.5^{\text {th }}$

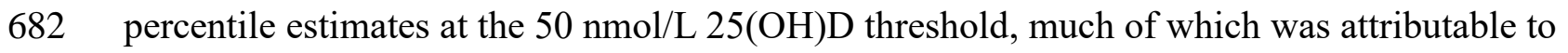

683 less than $10 \%$ of the population (i.e., moving from the $90^{\text {th }}$ to $97.5^{\text {th }}$ percentile). Sensitivity

684 analyses were used to explore the potential sources of this variability, as the $92 \mu \mathrm{g}$ vitamin

$685 \mathrm{D} /$ day required to maintain $97.5 \%$ of individuals with serum $25(\mathrm{OH}) \mathrm{D}>50 \mathrm{nmol} / \mathrm{L}$, based on

686 the unadjusted model, predicted an upper $97.5^{\text {th }}$ percentile serum $25(\mathrm{OH}) \mathrm{D}$ of $220 \mathrm{nmol} / \mathrm{L}$,

687 which is well in excess of the UL. Sub-group analysis for RCTs where compliance data were

688 available showed that at the $50 \mathrm{nmol} / \mathrm{L}$ serum $25(\mathrm{OH}) \mathrm{D}$ threshold, intake estimates at the

$68997.5^{\text {th }}$ percentile were 8.4 and $10.1 \mu \mathrm{g} / \mathrm{d}$ lower when a minimum compliance threshold of

$69080 \%$ and $95 \%$, respectively, were applied compared to estimates from the model not

691 accounting for compliance. In terms of other potential sources of variability, there can be

692 substantial variability associated with laboratory measurement of serum 25(OH)D [81]. The

693 use of standardized serum $25(\mathrm{OH}) \mathrm{D}$ data has many merits in overcoming some of this

694 method-related differences in estimates [82], but this is not always feasible, particularly for

695 RCTs. In addition, the estimates of total vitamin D intake used in the analyses are subject to

696 measurement errors arising from the variety of different dietary assessment techniques used

697 by the various RCTs. To estimate habitual vitamin D intakes, a time frame of sufficient

698 duration to capture infrequent food consumption (e.g. liver, fatty fish) is required (e.g. a

699 month is reasonable) [82], which is why many authors used validated FFQ methods to avoid

700 underreporting. On the other hand, it has been suggested that FFQ often tend to overestimate

701 nutrient intakes compared to food record-based approaches [82], however this has not been

702 verified for vitamin D. Differences in the coverage of vitamin D in foods within different

703 food compositional databases [1,25] used to estimate vitamin D intake, as well as the vitamin

704 D compounds included, may also have introduced variability into our analysis. Our

705 sensitivity analyses showed that adjusting for method of vitamin D assessment and for

706 method of serum $25(\mathrm{OH}) \mathrm{D}$ measurement increased the intake estimates at the $97.5^{\text {th }}$

707 percentile by $0.7,1.4$ and $10 \mu \mathrm{g} / \mathrm{d}$, and $1.1,2.2$ and $16.7 \mu \mathrm{g} / \mathrm{d}$, respectively, at the respective 
$\geq 25, \geq 30$ and $\geq 50$ serum $25(\mathrm{OH}) \mathrm{D}$ thresholds. In addition, the leave-one-out sensitivity analysis did not highlight use of chromatographic versus non-chromatographic or FFQ versus non-FFQ methods of vitamin D status and intake assessment in RCTs, respectively, as key factors in driving the high RDA estimates at the $50 \mathrm{nmol} / \mathrm{L}$ threshold. While this sensitivity analysis also suggested there were no overly influential RCTs, it is possible that there was a conflation of the variability in compliance, intake estimates and $25(\mathrm{OH}) \mathrm{D}$ analytical data, which when combined with between-individual variability in dose-response, contributed to the very high DRV estimates at the $50 \mathrm{nmol} / \mathrm{L}$ threshold in the unadjusted analysis.

The strengths of the present work include the application of the IPD approach to the data from 11 vitamin D-fortified food-based RCTs in both children and adults which met or exceed the eligibility criteria of IOM and/or EFSA, and which were identified through a systematic review thus increasing the external validity of our findings. Study quality was generally high and the majority of data are recent, with 9 of 11 of trials published in the last 7 years. The majority of studies had a low risk of bias across the 7 categories.

In conclusion, this IPD analyses of food-based vitamin D RCTs has provided new DRV estimates for vitamin D using models both adjusted and unadjusted for baseline serum 25(OH)D and other covariates. The approach used for data analysis, including model and adjustments included, had a profound impact on the DRV estimates generated. The work highlights the importance of being able to capture between-participant variability, crucial for estimating individual-based DRV recommendations. The DRV estimates for the $50 \mathrm{nmol} / \mathrm{L}$ $25(\mathrm{OH}) \mathrm{D}$ threshold both here and from our previous supplement trial-based IPD analysis are higher than the recommendations from NNR, IOM and EFSA, which used standard metaregression based on aggregate data from vitamin D supplement RCTs. The present IPD also shows that the RNI and RI/RDA estimates at the 25 and $50 \mathrm{nmol} / \mathrm{L}$ serum $25(\mathrm{OH}) \mathrm{D}$ threshold, respectively, for children are $\geq 2$ times lower than those for adults, which differs from agency reports to date. Finally, the IPD work also further informs and adds to the evidence-base around implementation of food-based approaches to tackle inadequate vitamin D intake and status. For example, the present findings provide evidence on how using foodbased approaches in attaining an intake of $\sim 12 \mu \mathrm{g} / \mathrm{d}$ could prevent very low vitamin D status (i.e., serum $25(\mathrm{OH}) \mathrm{D}<30 \mathrm{nmol} / \mathrm{L}$ ), with significant potential for public health benefit. 
738

739

740

741

742

743

744

745

746

747

748

749

750

751

752

753

754

755

756

757

758

759

760

761

762

763

764

765

766

767

768

769

770

771

\section{Declarations}

\section{Authors' contributions to the manuscript}

KDC, MEK and CR designed the research; KDC and MEK defined the eligibility criteria for the food-based vitamin D randomized controlled trials (RCTs) for inclusion in the individual participant data (IPD)-level meta-regression analysis; KDC conducted the electronic searches; Study selection and decision on which met the eligibility criteria and we included was conducted by KDC and MEK; KDC, LT and MEK performed the quality assessment of eligible studies; KDC, RA, IMG, KHM, JN, IT, LT, SAL-N, LT, MPV, UT, GJ, VVM, BLS, JH, AK, DW, RV, IO, PKA, NRB, HAW accessed, formatted and supplied the IPD from their 11 included RCTs which formed the core pooled dataset upon which this work was based; An assessment of the risk of bias in the included RCTs was performed by KDC and LT; CR performed the statistical analyses and derivation of vitamin D dietary reference value estimates; KDC and CR wrote the first draft of the paper, with all authors providing input and comment on subsequent versions; All authors read and approved the final manuscript.

\section{Funding: None}

Code availability: The $\mathrm{R}$ code for fitting linear and nonlinear models is presented in Cashman KD, Ritz C (2019). Individual participant data (IPD)-level meta-analysis of randomised controlled trials among dark-skinned populations to estimate the dietary requirement for vitamin D. Syst Rev 8:128. doi: 10.1186/s13643-019-1032-6.

\section{Compliance with ethical standards}

\section{Ethics standards}

Approval by a research ethics committee to conduct this meta-analysis was not required because the aim of this secondary analysis was consistent with the ethical approval received for the individual studies. The current analysis was conducted on anonymized data.

\section{Conflicts of Interest:}

The following authors had no conflicts of interest: Kevin D. Cashman, Mairead E. Kiely, Rikke Andersen, Ida M. Grønborg, Katja H. Madsen, Janna Nissen, Inge Tetens, Laura Tripkovic, Laura Toxqui, M. Pilar Vaquero, Ulrike Trautvetter, Gerhard Jahreis, Vikram V. Mistry, Bonny L. Specker, Jürgen Hower, Anette Knoll, Dennis Wagner, Reinhold Vieth, Inger Öhlund, Pia Karlsland Åkeson, Neil R. Brett, Christian Ritz. 
773 Hope A. Weiler at the time of the trial received a small speaker's honoraria for presenting at 774 the annual conferences organized by Dairy Farmers of Canada [Weiler H. Role of dairy in 775 body composition and health. Dairy Research Symposium, Dairy Farmers of Canada and 776 Agriculture Canada, Ottawa, Feb 5, 2016].

777 Susan A. Lanham-New is Research Director of D3Tex Ltd which holds the UK and Gulf 778 Corporation Council (GCC) Patents for the use of UVB material in preventing vitamin D 779 deficiency in women who dress for cultural style. SLN also received a small speaker's 780 honoraria for presentations at two conferences on Vitamin D organised by Solaris. 
783

784

785

786

787

788

789

790

791

792

793

794

795

796

797

798

799

800

801

802

803

804

805

806

807

808

809

810

811

812

813

814

815

816

817

818

\section{References}

1. Cashman KD, Kiely M (2011). Towards prevention of vitamin D deficiency and beyond: knowledge gaps and research needs in vitamin D nutrition and public health. Br J Nutr 106:1617-27.

2. Cashman KD, Dowling KG, Škrabáková Z, Gonzalez-Gross M, Valtueña J, De Henauw S, Moreno L, Damsgaard CT, Michaelsen KF, Mølgaard C, et al. (2016) Vitamin D deficiency in Europe: pandemic? Am J Clin Nutr 103:1033-44

3. Pilz S, März W, Cashman KD, Kiely ME, Whiting SJ, Holick MF, Grant WB, Pludowski P, Hiligsmann M, Trummer C, et al. (2018) Rationale and plan for vitamin D food fortification: A review and guidance paper. Front Endocrinol (Lausanne). 9:373.

4. Institute of Medicine: Dietary Reference Intakes for calcium and vitamin D. Washington, DC: The National Academies Press, 2011.

5. Brooks SPJ, Greene-Finestone L, Whiting S, Fioletov VE, Laffey P, Petronella N (2017). An analysis of factors associated with 25-Hydroxyvitamin D levels in white and nonwhite Canadians. J AOAC Int 100:1345-1354.

6. Herrick KA, Storandt RJ, Afful J, Pfeiffer CM, Schleicher RL, Gahche JJ, Potischman N (2019). Vitamin D status in the United States, 2011-2014. Am J Clin Nutr May 110:150157.

7. EFSA NDA Panel (EFSA Panel on Dietetic Products, Nutrition and Allergies) (2016). Scientific opinion on Dietary Reference Values for vitamin D. EFSA Journal, doi:10.2903/j.efsa.2016.

8. Nordic Council of Ministers (2014). Nordic Nutrition Recommendations 2012, 5th Edition (NNR5). Vitamin D. http://dx.doi.org/10.6027/Nord2014-002 (accessed April 2020).

9. Scientific Advisory Committee on Nutrition. Report on Vitamin D and Health (2016) Published online at: https://www.gov.uk/government/uploads/system/uploads/attachment_data/file/537616/S ACN_Vitamin_D_and_Health_report.pdf (accessed July 21st, 2016)

10. Holick MF, Binkley NC, Bischoff-Ferrari HA, Gordon CM, Hanley DA, Heaney RP, Murad MH, Weaver CM; Endocrine Society (2011). Evaluation, treatment, and prevention of vitamin D deficiency: an Endocrine Society clinical practice guideline. $\mathbf{J}$ Clin Endocrinol Metab 96:1911-1930.

11. Rejnmark L, Bislev LS, Cashman KD, Eiríksdottir G, Gaksch M, Grübler M, Grimnes G, Gudnason V, Lips P, Pilz S, van Schoor NM, Kiely M, Jorde R (2017). Non-skeletal health effects of vitamin D supplementation: A systematic review on findings from metaanalyses summarizing trial data. PLoS One 12:e0180512. 
12. Autier P, Mullie P, Macacu A, Dragomir M, Boniol M, Coppens K, Pizot C, Boniol M (2017). Effect of vitamin D supplementation on non-skeletal disorders: a systematic review of meta-analyses and randomised trials. Lancet Diabetes Endocrinol 5:986-1004.

13. Maretzke F, Bechthold A, Egert S, Ernst JB, Melo van Lent D, Pilz S, Reichrath J, Stangl GI, Stehle P, Volkert D, et al. (2020). Role of vitamin D in preventing and treating selected extraskeletal diseases - An umbrella review. Nutrients 12. pii: E969.

14. Cashman KD (2019). Vitamin D deficiency: Defining, prevalence, causes, and strategies of addressing. Calcif Tissue Int. May 8. doi: 10.1007/s00223-019-00559-4.

15. Roman Viñas B, Ribas Barba L, Ngo J, Gurinovic M, Novakovic R, Cavelaars A, de Groot LC, van't Veer P, Matthys C, Serra Majem L (2011). Projected prevalence of inadequate nutrient intakes in Europe. Ann Nutr Metab 59:84-95.

16. Elmadfa I, Meyer A, Nowak V, Hasenegger V, Putz P, Verstraeten R, Remaut-DeWinter AM, Kolsteren P, Dostálová J, Dlouhý P et al (2009). European Nutrition and Health Report 2009. Ann Nutr Metab 55:1-40.

17. Shakur YA, Lou W, L'Abbe MR (2014). Examining the effects of increased vitamin D fortification on dietary inadequacy in Canada. Can J Public Health.;105:e127-32.

18. Newman JC, Malek AM, Hunt KJ, Marriott BP (2019). Nutrients in the US Diet: Naturally occurring or enriched/fortified food and beverage sources, plus dietary supplements: NHANES 2009-2012. J Nutr 149:1404-1412.

19. Kiely M, Black LJ (2012). Dietary strategies to maintain adequacy of circulating 25hydroxyvitamin D concentrations, Scand J Clin Lab Invest Suppl 243:14-23.

20. Allen L, de Benoist B, Dary O, Hurrell R (2006). Guidelines on food fortification with micronutrients. World Health Organization and Food and Agriculture Organization of the United Nations. Geneva, 2006. http://apps.who.int/iris/bitstream/10665/43412/1/9241594012_eng.pdf (accessed 28 June 2016)

21. Black LJ, Seamans KM, Cashman KD, Kiely M (2012). An updated systematic review and meta-analysis of the efficacy of vitamin D food fortification. J Nutr 142:1102-8.

22. O’Donnell S, Cranney A, Horsley T, Weiler HA, Atkinson SA, Hanley DA, Ooi DS, Ward L, Barrowman N, Fang M, Sampson M, Tsertsvadze A, Yazdi F (2008). Efficacy of food fortification on serum 25-hydroxyvitamin D concentrations: systematic review. Am J Clin Nutr 88:1528-1534.

23. Cashman KD, Kiely M (2016). Tackling inadequate vitamin D intakes within the population: fortification of dairy products with vitamin D may not be enough, Endocrine 51:38-46.

24. Itkonen ST, Erkkola M, Lamberg-Allardt CJE (2018). Vitamin D fortification of fluid milk products and their contribution to vitamin D intake and vitamin D status in observational studies-A review. Nutrients 10. pii: E1054. 
25. Hayes A, Cashman KD (2017). Food-based solutions for vitamin D deficiency: putting policy into practice and the key role for research. Proc Nutr Soc ;76(1):54-63.

26. Brett NR, Gharibeh N, Weiler HA (2018). Effect of vitamin D supplementation, food fortification, or bolus injection on vitamin D status in children aged 2-18 Years: A metaanalysis. Adv Nutr 9:454-464.

27. Vale CL, Rydzewska LH, Rovers, MM, Emberson JR, Gueyffier F, Stewart LA, Cochrane IPD Meta-Analysis Methods Group (2015). Uptake of systematic reviews and meta-analyses based on individual participant data in clinical practice guidelines: Descriptive study. BMJ 350:h1088.

28. Cashman KD, Ritz C, Kiely M, Odin Collaborators (2017). Improved dietary guidelines for vitamin D: Application of Individual Participant Data (IPD)-level meta-regression analyses. Nutrients 9. pii: E469.

29. Cashman KD (2018). Vitamin D requirements for the future - lessons learned and charting a path forward. Nutrients 10. pii: E533.

30. Seamans KM, Cashman KD (2009). Existing and potentially novel functional markers of vitamin D status: a systematic review. Am J Clin Nutr 89:1997S-2008S.

31. Cashman KD, Fitzgerald AP, Kiely M, Seamans KM (2011). A systematic review and meta-regression analysis of the vitamin D intake-serum 25-hydroxyvitamin D relationship to inform European recommendations. Br J Nutr 106:1638-48.

32. Cashman KD, Kiely M, Seamans KM, Urbain P (2016). Effect of ultraviolet lightexposed mushrooms on vitamin D status: Liquid chromatography-tandem mass spectrometry reanalysis of biobanked sera from a randomized controlled trial and a systematic review plus meta-analysis. J Nutr 146:565-75.

33. Stewart LA, Clarke M, Rovers M, Riley RD, Simmonds M, Stewart G, Tierney JF, PRISMA-IPD Development Group (2015). Preferred eporting Items for Systematic Review and Meta-Analyses of individual participant data: the PRISMA-IPD Statement. JAMA 313:1657-65.

34. Cashman KD, Ritz C (2019). Individual participant data (IPD)-level meta-analysis of randomised controlled trials among dark-skinned populations to estimate the dietary requirement for vitamin D. Syst Rev 8:128. doi: 10.1186/s13643-019-1032-6.

35. Brouwer-Brolsma EM, Berendsen AAM, Vaes AMM, Dullemeijer C, de Groot LCPGM and Feskens EJM (2016). Collection and analysis of published scientific information as preparatory work for the setting of Dietary Reference Values for Vitamin D. EFSA supporting publication, EN-766, $171 \mathrm{pp}$.

36. EFSA (European Food Safety Authority) (2012). Scientific opinion on the tolerable upper intake level of vitamin D. EFSA Journal;10:2813.

37. Rooney MR, Harnack L, Michos ED, Ogilvie RP, Sempos CT, Lutsey PL (2017). Trends in use of high-dose vitamin D supplements exceeding 1000 or 4000 International Units daily, 1999-2014. JAMA 317(23):2448-2450. 
38. Tripkovic L, Lambert H, Hart K, Smith CP, Bucca G, Penson S, Chope G, Hyppönen, E, Berry J, Vieth R, et al (2012). Comparison of vitamin $\mathrm{D}_{2}$ and vitamin $\mathrm{D}_{3}$ supplementation in raising serum 25-hydroxyvitamin D status: a systematic review and meta-analysis. Am J Clin Nutr 95:1357-1364.

39. Autier P, Gandini S, Mullie P (2012). A systematic review: Influence of vitamin D supplementation on serum 25-hydroxyvitamin D concentration. J Clin Endocrinol Metabol 97:2606-2613.

40. Cashman KD, Hayes A, O'Donovan SM, Zhang JY, Kinsella M, Galvin K, Kiely M, Seamans KM (2014). Dietary calcium does not interact with vitamin $\mathrm{D}_{3}$ in terms of determining the response and catabolism of serum 25-hydroxyvitamin D during winter in older adults. Am J Clin Nutr 99:1414-23.

41. Cashman KD (2015). Vitamin D: dietary requirements and food fortification as a means of helping achieve adequate vitamin D status. J Steroid Biochem Mol Biol 148:19-26.

42. Harris SS, Dawson-Hughes B (2002). Plasma vitamin D and 25(OH)D responses of young and old men to supplementation with vitamin $\mathrm{D}_{3}$. J Am Coll Nutr 21:357-362.

43. Cashman KD, Hill TR, Lucey AJ, Taylor N, Seamans KM, Muldowney S, Fitzgerald AP, Flynn A, Barnes MS, Horigan G, et al (2008). Estimation of the dietary requirement for vitamin D in healthy adults. Am J Clin Nutr 88:1535-42.

44. Cashman KD, Wallace JM, Horigan G, Hill TR, Barnes MS, Lucey AJ, Bonham MP, Taylor N, Duffy EM, Seamans K, et al (2009). Estimation of the dietary requirement for vitamin $\mathrm{D}$ in free-living adults $>=64 \mathrm{y}$ of age. Am J Clin Nutr 89:1366-74.

45. Moher D, Liberati A, Tetzlaff J, Altman DG, Group P (2009). Preferred reporting items for systematic reviews and meta-analyses: the PRISMA statement. BMJ 339:2535.

46. Stewart LA, Tierney JF, Clarke M, on behalf of the Cochrane Individual Patient Data Meta-analysis Methods Group (2011). Chapter 18: Reviews of individual patient data. In: Higgins JPT, Green S, editors. Part 3: Special topics. Cochrane Handbook for Systematic Reviews of Interventions Version 5.1.0 [updated March 2011]. The Cochrane Collaboration, 2011. Available from http://handbook-51.cochrane.org/chapter_18/18_2_the_collaborative_nature_of_ipd_meta_analyses.htm

47. Ohmann C, Banzi R, Canham S, Battaglia S, Matei M, Ariyo C, Becnel L, Bierer B, Bowers S, Clivio L, et al. (2017). Sharing and reuse of individual participant data from clinical trials: principles and recommendations. BMJ Open 7:e018647. doi:10.1136/ bmjopen-2017-018647

48. Jadad AR, Moore RA, Carroll D, Jenkinson C, Reynolds DJM, Gavaghan DJ, McQuay HJ (1996). Assessing the quality of reports of randomized clinical trials: is blinding necessary? Control Clin Trials 17:1-12.

49. Higgins JPT, Altman DG, Sterne JAC, on behalf of the Cochrane Statistical Methods Group and the Cochrane Bias Methods Group (2011): Chapter 8: Assessing risk of bias 
934

935

936

937

938

939

940

941

942

943

944

945

946

947

948

949

950

951

952

953

954

955

956

957

958

959

960

961

962

963

964

965

966

967

968

969

970

971

in included studies. In: Higgins JPT, Green S, editors. Part 2: general methods for Cochrane reviews. Cochrane Handbook for Systematic Reviews of Interventions Version 5.1.0 The Cochrane Collaboration [Internet]. 2011 [updated 2011 Mar; cited 2015 Dec 18]. Available from: http://handbook.cochrane.org/ chapter_8/8_assessing_risk_of_bias_in_included_studies.htm.

50. Stewart GB, Altman DG, Askie LM, Duley L, Simmonds MC, Stewart LA (2012). Statistical analysis of individual participant data meta-analyses: A comparison of methods and recommendations for practice. PLoS One 7:e46042.

51. Morris TP, Fisher DJ, Kenward MG, Carpenter JR (2018). Meta-analysis of Gaussian individual patient data: Two-stage or not two-stage? Stat Med ;37(9):1419-1438.

52. Pan H, Cole TJ. LMS growth, a Microsoft Excel add-in to access growth references based on the LMS method. Version 2.2. [Online]. Available at http://www.healthforallchildren.co.uk/ [Accessed March 2014].

53. EFSA NDA Panel (EFSA Panel on Dietetic Products, Nutrition and Allergies) (2018). Scientific opinion on the update of the tolerable upper intake level for vitamin D for infants. EFSA Journal 2018;16:5365, 118 pp. https://doi.org/10.2903/j.efsa.2018.5365

54. Maurya VK, Aggarwal M (2017). Factors influencing the absorption of vitamin D in GIT: an overview. J Food Sci Technol 54:3753-3765.

55. Wagner D, Sidhom G, Whiting SJ, Rousseau D, Vieth R (2008). The bioavailability of vitamin $\mathrm{D}$ from fortified cheeses and supplements is equivalent in adults. J Nutr 138:1365-71

56. Biancuzzo RM, Young A, Bibuld D, Cai MH, Winter MR, Klein EK, Ameri A, Reitz R, Salameh W, Chen TC, et al (2010). Fortification of orange juice with vitamin $\mathrm{D}(2)$ or vitamin $\mathrm{D}(3)$ is as effective as an oral supplement in maintaining vitamin $\mathrm{D}$ status in adults. Am J Clin Nutr 91:1621-6.

57. Natri AM, Salo P, Vikstedt T, Palssa A, Huttunen M, Kärkkäinen MU, Salovaara H, Piironen V, Jakobsen J, Lamberg-Allardt CJ (2006). Bread fortified with cholecalciferol increases the serum 25-hydroxyvitamin D concentration in women as effectively as a cholecalciferol supplement. J Nutr 136:123-7.

58. Nikooyeh B, Neyestani TR, Zahedirad M, Mohammadi M, Hosseini SH, Abdollahi Z, Salehi F, Mirzay Razaz J, Shariatzadeh N, Kalayi A, et al (2016). Vitamin D-fortified bread is as effective as supplement in improving vitamin D status: A randomized clinical trial. J Clin Endocrinol Metab 101:2511-9.

59. Whiting SJ, Bonjour JP, Payen FD, Rousseau B (2015). Moderate amounts of vitamin $\mathrm{D}_{3}$ in supplements are effective in raising serum 25-hydroxyvitamin D from low baseline levels in adults: a systematic review. Nutrients 7:2311-23.

60. Bates D, Maechler M, Bolker B, Walker S (2015). Fitting linear mixed-effects models using lme4. J Stat Soft 67:1-48. 
972

973

974

975

976

977

978

979

980

981

982

983

984

985

986

987

988

989

990

991

992

993

994

995

996

997

998

999

1000

1001

1002

1003

1004

1005

1006

1007

1008

1009

1010

61. Pinheiro J, Bates D, DebRoy S, Sarkar D, R Core T. _nlme: linear and nonlinear mixed effects models. R package version. 2018;3:1-137.

62. Johnson JL, Mistry VV, Vukovich MD, Hogie-Lorenzen T, Hollis BW, Specker BL (2005). Bioavailability of vitamin D from fortified process cheese and effects on vitamin D status in the elderly. J Dairy Sci 88:2295-301.

63. Hower J, Knoll A, Ritzenthaler KL, Steiner C, Berwind R (2013). Vitamin D fortification of growing up milk prevents decrease of serum 25-hydroxyvitamin D concentrations during winter: a clinical intervention study in Germany. Eur J Pediatr 172:1597-605.

64. Madsen KH, Rasmussen LB, Andersen R, Mølgaard C, Jakobsen J, Bjerrum PJ, Andersen EW, Mejborn H, Tetens I (2013). Randomized controlled trial of the effects of vitamin D-fortified milk and bread on serum 25-hydroxyvitamin D concentrations in families in Denmark during winter: the VitmaD study. Am J Clin Nutr 98:374-82.

65. Toxqui L, Pérez-Granados AM, Blanco-Rojo R, Wright I, de la Piedra C, Vaquero MP (2014). Low iron status as a factor of increased bone resorption and effects of an iron and vitamin D-fortified skimmed milk on bone remodelling in young Spanish women. Eur J Nutr 53:441-8.

66. Trautvetter U, Neef N, Leiterer M, Kiehntopf M, Kratzsch J, Jahreis G (2014). Effect of calcium phosphate and vitamin $\mathrm{D}_{3}$ supplementation on bone remodelling and metabolism of calcium, phosphorus, magnesium and iron. Nutr J 13:6. doi: 10.1186/1475-2891-13-6.

67. Brett NR, Lavery P, Agellon S, Vanstone CA, Maguire JL, Rauch F, Weiler HA (2016). Dietary vitamin D dose-response in healthy children 2 to 8 y of age: a 12-wk randomized controlled trial using fortified foods. Am J Clin Nutr 103:144-52.

68. Hayes A, Duffy S, O'Grady M, Jakobsen J, Galvin K, Teahan-Dillon J, Kerry J, Kelly A, O'Doherty J, Higgins S, et al (2016). Vitamin D-enhanced eggs are protective of wintertime serum 25-hydroxyvitamin $\mathrm{D}$ in a randomized controlled trial of adults. Am J Clin Nutr 104:629-37.

69. Öhlund I, Lind T, Hernell O, Silfverdal SA, Karlsland Åkeson P (2017). Increased vitamin D intake differentiated according to skin color is needed to meet requirements in young Swedish children during winter: a double-blind randomized clinical trial. Am J Clin Nutr 106:105-112.

70. Tripkovic L, Wilson LR, Hart K, Johnsen S, de Lusignan S, Smith CP, Bucca G, Penson S, Chope G, Elliott R, et al (2017). Daily supplementation with $15 \mu$ g vitamin $D(2)$ compared with vitamin $\mathrm{D}(3)$ to increase wintertime 25 -hydroxyvitamin $\mathrm{D}$ status in healthy South Asian and white European women: a 12-wk randomized, placebocontrolled food-fortification trial. Am J Clin Nutr 106:481-490.

71. Grønborg IM, Tetens I, Christensen T, Andersen EW, Jakobsen J, Kiely M, Cashman KD, Andersen R (2020). Vitamin D-fortified foods improve wintertime vitamin D status 
in women of Danish and Pakistani origin living in Denmark: a randomized controlled trial. Eur J Nutr 59:741-753.

72. Mortensen C, Damsgaard CT, Hauger H, Ritz C, Lanham-New SA, Smith TJ, Hennessy Á, Dowling K, Cashman KD, Kiely M, et al (2016). Estimation of the dietary requirement for vitamin $\mathrm{D}$ in white children aged 4-8 y: a randomized, controlled, doseresponse trial. Am J Clin Nutr 104:1310-1317.

73. Smith TJ, Tripkovic L, Damsgaard CT, Mølgaard C, Ritz C, Wilson-Barnes SL, Dowling KG, Hennessy Á, Cashman KD, Kiely M, et al (2016). Estimation of the dietary requirement for vitamin $\mathrm{D}$ in adolescents aged 14-18 y: a dose-response, double-blind, randomized placebo-controlled trial. Am J Clin Nutr 104:1301-1309.

74. Cashman KD, Seamans KM, Lucey AJ, Stöcklin E, Weber P, Kiely M, Hill TR (2012). Relative effectiveness of oral 25-hydroxyvitamin D3 and vitamin D3 in raising wintertime serum 25-hydroxyvitamin D in older adults. Am J Clin Nutr 95:1350-6.

75. Cashman KD, Hayes A, O'Donovan SM, Zhang JY, Kinsella M, Galvin K, Kiely M, Seamans KM (2014). Dietary calcium does not interact with vitamin $\mathrm{D}_{3}$ in terms of determining the response and catabolism of serum 25-hydroxyvitamin D during winter in older adults. Am J Clin Nutr. 99:1414-23.

76. Ní Chaoimh C, McCarthy EK, Hourihane JO, Kenny LC, Irvine AD, Murray DM, Kiely ME (2018). Low vitamin D deficiency in Irish toddlers despite northerly latitude and a high prevalence of inadequate intakes. Eur J Nutr 57:783-794.

77. Drincic AT, Armas LA, Van Diest EE, Heaney RP (2012). Volumetric dilution, rather than sequestration best explains the low vitamin D status of obesity. Obesity (Silver Spring). 20:1444-8.

78. Cashman KD, Kiely M (2017). Vitamin D and food fortification. In: Vitamin D, 4th Edition. (Editors: David Feldman J. Wesley Pike, Roger Bouillon, Edward Giovannucci, David Goltzman and Martin Hewison). Elsevier.

79. Raulio S, Erlund I, Männistö S, Sarlio-Lähteenkorva S, Sundvall J, Tapanainen H, Vartiainen E, Virtanen SM (2017). Successful nutrition policy: improvement of vitamin D intake and status in Finnish adults over the last decade. Eur J Public Health 27:268273.

80. Jääskeläinen T, Itkonen ST, Lundqvist A, Erkkola M, Koskela T, Lakkala K, Dowling KG, Hull GL, Kröger H, Karppinen J, et al. (2017). The positive impact of general vitamin $\mathrm{D}$ food fortification policy on vitamin $\mathrm{D}$ status in a representative adult Finnish population: evidence from an 11-y follow-up based on standardized 25-hydroxyvitamin D data. Am J Clin Nutr 105:1512-1520.

81. Carter GD (2011). Accuracy of 25-hydroxyvitamin D assays: confronting the issues. Curr Drug Targets 12:19-28.

82. Brooks SPJ, Sempos CT (2017). The importance of 25-Hydroxyvitamin D assay standardization and the vitamin D standardization program. J AOAC Int 100:1223-1224. 
1050

1051 83. Willet W (2013). Nutritional Epidemiology, 3rd edn. New York, NY: Oxford University 1052 Press. 
Table 1. Selected design parameters of the 11 randomized controlled trials with vitamin $D$-fortified food, conducted in winter and $\geq 40^{\circ} \mathrm{N}$, as well as baseline and vitamin D-related outcome characteristics of white subjects who completed the intervention studies and were included in data analyses*.

\begin{tabular}{|c|c|c|c|c|}
\hline Study & Johnson et al. 2005 & Wagner et al. 2008 & Madsen et al. 2013 & Toxqui et al. 2014 \\
\hline (Reference Number) & {$[62]$} & {$[57]$} & {$[64]$} & {$[65]$} \\
\hline Trial registry ID & NR & NR & NCT01184716 & NCT01739907 \\
\hline \multicolumn{5}{|l|}{ Design parameters: } \\
\hline Location $\left({ }^{\circ} \mathrm{N}\right)$ & USA $\left(\sim 44^{\circ} \mathrm{N}\right)$ & Canada $\left(43^{\circ} \mathrm{N}\right)$ & Denmark $\left(56^{\circ} \mathrm{N}\right)$ & Spain $\left(40.2^{\circ} \mathrm{N}\right)$ \\
\hline Year of study & 2004 & 2007 & 2010-2011 & 2012 \\
\hline Duration (and Months) & 2 months (within Dec-April) & 8 weeks (within Jan-April) & 6 months (Sept-April) & 8 weeks (within January-March)** \\
\hline $\begin{array}{l}\text { Food interventions } \\
\text { [supplemental } \\
\text { vitamin } \mathrm{D}_{3} \text { dose] }\end{array}$ & $\begin{array}{c}\text { Vit D-fortified cheese }[15 \mu \mathrm{g} / \mathrm{d}] \\
v . \text { Non-fortified cheese } v \text {. No } \\
\text { cheese }\end{array}$ & $\begin{array}{c}\text { Fortified }[700 \mu \mathrm{g} / \mathrm{wk}] v . \\
\text { Low fat-fortified [700 } \\
\mu \mathrm{g} / \mathrm{wk}] v . \text { Placebo cheese }\end{array}$ & $\begin{array}{c}\text { Vit D-fortified } 0.5 \% \text { milk } \\
\text { + bread (wheat } / \text { rye) }[6.8 \mu \mathrm{g} / \mathrm{d} \text {, on } \\
\text { average] } v \text {. Non-fortified milk and } \\
\text { bread }\end{array}$ & $\begin{array}{l}\text { Fe and Vit D-fortified skimmed } \\
\quad \text { cow's milk [ } 5 \mu \mathrm{g} / \mathrm{d}] v \text {. } \\
\text { Fe-fortified skimmed cow's milk }\end{array}$ \\
\hline \multicolumn{5}{|l|}{ Subject characteristics: } \\
\hline \multicolumn{5}{|l|}{ Baseline } \\
\hline $\bar{N}$ & 90 & 50 & 682 & 107 \\
\hline Sex (Male:Female) & $34: 56$ & $25: 25$ & $330: 352$ & 0:107 \\
\hline Age (year) & $73.5 \pm 7.2^{1}$ & $27.8 \pm 9.6$ & $27.2 \pm 16.3$ & $24.9 \pm 4.4$ \\
\hline Weight (kg) & $79.8 \pm 15.8$ & $68.2 \pm 14.6$ & $60.6 \pm 24.8$ & $59.5 \pm 8.9$ \\
\hline BMI $\left(\mathrm{kg} / \mathrm{m}^{2}\right)$ & $28.3 \pm 5.2$ & $23.8 \pm 4.2$ & $21.9 \pm 5.4$ & $21.7 \pm 3.0$ \\
\hline Dietary vitamin $D(\mu \mathrm{g} / \text { day })^{2}$ & $11.1 \pm 7.8^{\mathrm{d}}$ & $3.2 \pm 2.3^{\mathrm{a}}$ & $2.8 \pm 1.7^{\mathrm{a}}$ & $2.9 \pm 2.8^{\mathrm{b}}$ \\
\hline Serum $25(\mathrm{OH}) \mathrm{D}(\mathrm{nmol} / \mathrm{L})^{3}$ & $51.8 \pm 19.3^{\mathrm{e}}$ & $53.8 \pm 21.4^{\mathrm{e}}$ & $74.8 \pm 19.9^{\mathrm{f}}$ & $61.7 \pm 19.6^{\mathrm{i}}$ \\
\hline \multicolumn{5}{|l|}{ Endpoint } \\
\hline \multicolumn{5}{|l|}{ Dietary vitamin $\mathrm{D}(\mu \mathrm{g} / \text { day })^{4}$ : } \\
\hline Control group $(s)(n)$ & $10.9 \pm 8.1(61)$ & $3.9 \pm 3.0(20)$ & $4.2 \pm 3.8(353)$ & $2.9 \pm 2.5(52)$ \\
\hline Vit $D$ intervention group $(s)(n)$ & $26.0 \pm 7.1$ & $103.9 \pm 3.3(30)$ & $13.5 \pm 6.9(329)$ & $7.3 \pm 3.3(55)$ \\
\hline \multicolumn{5}{|l|}{ Serum 25(OH)D $(\mathrm{nmol} / \mathrm{L})^{3,4}$ : } \\
\hline Control group $(s)(n)$ & $51.0 \pm 16.3(61)$ & $50.7 \pm 24.2(20)$ & $45.1 \pm 20.2$ & $58.1 \pm 17.5(52)$ \\
\hline Vit D intervention group $(s)(n)$ & $53.2 \pm 19.9$ & $120.0 \pm 28.2$ & $70.0 \pm 19.0$ & $65.7 \pm 16.6$ \\
\hline
\end{tabular}




\begin{tabular}{|c|c|c|c|c|}
\hline Study & Trautvetter et al. 2014 & Hayes et al. 2016 & Tripkovic et al. 2017 & Grønborg et al. 2019 \\
\hline (Reference Number) & {$[66]$} & {$[68]$} & {$[70]$} & {$[71]$} \\
\hline Trial registry ID & NCT01297023 & NCT02678364 & ISRCTN23421591 & NCT02631629 \\
\hline \multicolumn{5}{|l|}{ Design parameters: } \\
\hline Location $\left({ }^{\circ} \mathrm{N}\right)$ & Germany $\left(51^{\circ} \mathrm{N}\right)$ & Ireland $\left(51.9^{\circ} \mathrm{N}\right)$ & $\mathrm{UK}\left(51.3^{\circ} \mathrm{N}\right)$ & Denmark $\left(56^{\circ} \mathrm{N}\right)$ \\
\hline Year of study & 2011 & 2015 & 2011-2012 and 2012-2013 & 2016 \\
\hline Duration (and Months) & 8 weeks (within Jan-April) & 8 weeks (within Jan-March) & 12 weeks (within Oct-March) & 3 month (Jan-March) \\
\hline $\begin{array}{l}\text { Food interventions } \\
\text { [supplemental } \\
\text { vitamin } D_{3} \text { dose] }\end{array}$ & $\begin{array}{c}\mathrm{CaP} v . \text { Vit } \mathrm{D} v \cdot \mathrm{CaP}+\mathrm{Vit} \mathrm{D} \\
{[10 \mu \mathrm{g} / \mathrm{d}]} \\
\text {-fortified bread }\end{array}$ & $\begin{array}{c}\text { Vit D [3.5 } \mu \mathrm{g} / \mathrm{d}]-v .25-(\mathrm{OH}) \mathrm{D} \\
{[4.5 \mu \mathrm{g} / \mathrm{d}]-\text { fortified eggs } v} \\
\text { Control eggs }\end{array}$ & $\begin{array}{c}\text { Vit } D_{3} \text {-fortified Orange Juice } \\
{[15 \mu \mathrm{g} / \mathrm{d}] v \text {. Vit } \mathrm{D}_{3} \text {-fortified }} \\
\text { Biscuit }[15 \mu \mathrm{g} / \mathrm{d}] \\
v \text {. Placebo }\end{array}$ & $\begin{array}{l}\text { Vitamin D-fortified low-fat } \\
\text { cheese, yoghurt, eggs and } \\
\text { crisp bread (supplying } 30 \\
\mu \mathrm{g} / \mathrm{d} \text { in total) } v \text {. non- } \\
\text { fortified equivalents }\end{array}$ \\
\hline \multicolumn{5}{|l|}{ Subject characteristics: } \\
\hline \multicolumn{5}{|l|}{ Baseline } \\
\hline $\bar{N}$ & 55 & 50 & 133 & 60 \\
\hline Sex (Male:Female) & $23: 32$ & $26: 24$ & $0: 133$ & $0: 60$ \\
\hline Age (year) & $42.8 \pm 12.1$ & $54.9 \pm 6.4$ & $46.2 \pm 12.1$ & $33.3 \pm 11.3$ \\
\hline Weight (kg) & $72.9 \pm 14.3$ & $73.7 \pm 15.1$ & $65.5 \pm 10.8$ & $67.8 \pm 12.0$ \\
\hline $\operatorname{BMI}\left(\mathrm{kg} / \mathrm{m}^{2}\right)$ & $24.8 \pm 3.9$ & $25.4 \pm 4.1$ & $23.8 \pm 3.5$ & $24.1 \pm 4.1$ \\
\hline Dietary vitamin D $(\mu \mathrm{g} / \text { day })^{2}$ & $3.6 \pm 4.1^{\mathrm{d}}$ & $6.6 \pm 3.8^{\mathrm{a}}$ & $2.9 \pm 2.4^{\mathrm{c}}$ & $1.5 \pm 0.8^{\mathrm{a}}$ \\
\hline Serum $25(\mathrm{OH}) \mathrm{D}(\mathrm{nmol} / \mathrm{L})^{3}$ & $50.8 \pm 21.8^{\mathrm{h}}$ & $45.9 \pm 16.4^{\mathrm{f}}$ & $60.2 \pm 24.7^{f}$ & $48.6 \pm 16.3^{f}$ \\
\hline \multicolumn{5}{|l|}{ Endpoint } \\
\hline \multicolumn{5}{|l|}{ Dietary vitamin $\mathrm{D}(\mu \mathrm{g} / \text { day })^{4}$ : } \\
\hline Control group $(s)(n)$ & $6.6 \pm 0.5(18)$ & $6.0 \pm 2.7(16)$ & $2.5 \pm 2.3$ & $1.5 \pm 0.7(31)$ \\
\hline Vit D intervention group $(s)(n)$ & $15.0 \pm 0.8$ & $10.0 \pm 3.8$ & $8.1 \pm 2.5(90)$ & $28.7 \pm 8.8(29)$ \\
\hline \multicolumn{5}{|l|}{ Serum $25(\mathrm{OH}) \mathrm{D}(\mathrm{nmol} / \mathrm{L})^{3,4}$ : } \\
\hline Control group $(s)(n)$ & $47.4 \pm 30.3(18)$ & $35.1 \pm 11.0$ & $44.1 \pm 17.8$ & $44.0 \pm 16.7$ \\
\hline Vit $D$ intervention group $(s)(n)$ & $67.7 \pm 13.9$ & $48.5 \pm 18.7$ & $90.7 \pm 24.0$ & $77.8 \pm 14.4$ \\
\hline
\end{tabular}




\begin{tabular}{|c|c|c|c|}
\hline Study & Hower et al. 2013 & Brett et al. 2016 & Öhlund et al. 2017 \\
\hline (Reference Number) & {$[63]$} & {$[67]$} & {$[69]$} \\
\hline Trial registry ID & NR & NCT02097160 & NCT01741324 \\
\hline \multicolumn{4}{|l|}{ Design parameters: } \\
\hline Location $\left({ }^{\circ} \mathrm{N}\right)$ & Germany $\left(51^{\circ} \mathrm{N}\right)$ & Canada $\left(45.5^{\circ} \mathrm{N}\right)$ & Sweden $\left(55\right.$ and $\left.63^{\circ} \mathrm{N}\right)$ \\
\hline Year of study & 2010-2011 & 2014 & $2012-2013$ \\
\hline Duration (and Months) & 4 months $(\mathrm{Nov}-\mathrm{Feb})^{* *}$ & 12 weeks (Jan-April) & 3 months (within Nov-March) \\
\hline $\begin{array}{l}\text { Food interventions [supplemental } \\
\text { vitamin } D_{3} \text { dose] }\end{array}$ & $\begin{array}{c}\text { Vit D-fortified growing up milk } \\
{[10 \mu \mathrm{g} / \mathrm{d}] v \text {. Semi-skimmed cow's milk with }} \\
\text { no added vitamin D }\end{array}$ & $\begin{array}{l}\text { Vit D-fortified drinkable yogurt + } \\
\text { cheese (providing } 10 \text { or } 15 \mu \mathrm{g} / \mathrm{d} \text { ) } \\
v . \text { non-fortified yogurt + cheese }\end{array}$ & $\begin{array}{c}\text { Vit D-fortified lactose-free, UHT milk } \\
\text { [12 or } 22 \mu \mathrm{g} / \mathrm{d}] v . \text { non-fortified } \\
\text { lactose-free, UHT milk }\end{array}$ \\
\hline \multicolumn{4}{|l|}{ Subject characteristics: } \\
\hline \multicolumn{4}{|l|}{ Baseline } \\
\hline $\bar{n}+n$ & 62 & 43 & 97 \\
\hline Sex (Male:Female) & $32: 30$ & 22:21 & 45:52 \\
\hline Age (year) & $3.7 \pm 1.2$ & $5.5 \pm 1.8$ & $6.3 \pm 0.6$ \\
\hline Weight $(\mathrm{kg})$ & $16.3 \pm 3.4$ & $21.4 \pm 5.9$ & $23.1 \pm 3.6$ \\
\hline $\operatorname{BMI}\left(\mathrm{kg} / \mathrm{m}^{2}\right)[\mathrm{z}$ score $]$ & $15.9 \pm 1.5[0.16 \pm 1.0]$ & $16.4 \pm 1.4[0.43 \pm 0.81]$ & $15.8 \pm 1.5[0.04 \pm 1.0]$ \\
\hline Dietary vitamin $\mathrm{D}(\mu \mathrm{g} / \text { day })^{2}$ & $2.2 \pm 1.4^{\mathrm{a}}$ & $5.2 \pm 2.6^{\mathrm{a}}$ & $5.5 \pm 2.7^{\mathrm{a}}$ \\
\hline Serum 25(OH)D $(\mathrm{nmol} / \mathrm{L})^{3}$ & $54.7 \pm 18.8^{\mathrm{i}}$ & $60.9 \pm 12.5^{\mathrm{e}}$ & $63.9 \pm 16.9^{f}$ \\
\hline \multicolumn{4}{|l|}{ Endpoint } \\
\hline \multicolumn{4}{|l|}{ Dietary vitamin $\mathrm{D}(\mu \mathrm{g} / \text { day })^{4}$ : } \\
\hline Control group $(s)(n)$ & $2.5 \pm 1.5(23)$ & $6.2 \pm 1.8(15)$ & $6.3 \pm 2.4(18)$ \\
\hline Vit D intervention group $(s)(n)$ & $8.7 \pm 2.8$ & $12.8 \pm 3.8(28)$ & $22.4 \pm 6.0(79)$ \\
\hline \multicolumn{4}{|l|}{ Serum 25(OH)D (nmol/L) $)^{3,4}$ : } \\
\hline Control group $(s)(n)$ & $37.4 \pm 16.6(23)$ & $58.6 \pm 13.1(15)$ & $59.2 \pm 14.5(18)$ \\
\hline Vit D intervention group $(s)(n)$ & $64.2 \pm 22.9$ & $63.6 \pm 12.0(28)$ & $80.5 \pm 16.6(79)$ \\
\hline
\end{tabular}

*In some cases, additional participants in the study were not included in the analyses as they did not meet with the inclusion criteria (total $n=489$ ).

${ }^{* *}$ Not study endpoint but sampling point which fit with sampling months as specified by inclusion criteria. ${ }^{1}$ Mean \pm SD (all such values).

${ }^{2}$ Habitual dietary vitamin D intake assessed via semi-quantitative FFQ ${ }^{a}$, 72-h detailed dietary intake report ${ }^{\mathrm{b}}$, 4-day diet diary ${ }^{\mathrm{c}}$, or 3-day diet records ${ }^{\mathrm{d}}$.

${ }^{3}$ Serum 25(OH)D measured by RIA ${ }^{\mathrm{e}}$, LC-MS/MS ${ }^{\mathrm{f}}, \mathrm{HPLC}^{\mathrm{g}}$, ELISA ${ }^{\mathrm{h}}$, or chemiluminescence immunoassay ${ }^{\mathrm{i}}$.

${ }^{4}$ In studies where there were more than one control and/or vitamin D intervention groups, reported values are for all control or vitamin $\mathrm{D}$ intervention subjects.

BMI, body mass index; 25(OH)D, 25-hydroxyvitamin D; NR, not registered. 
Table 2. Individual Participant Data (IPD) meta-analysis-derived dietary requirements for vitamin D ( $\mu \mathrm{g} / \mathrm{day}$ ) for allowing $97.5 \%$ of individuals to maintain serum $25(\mathrm{OH}) \mathrm{D}$ at or above three recommended thresholds ${ }^{l}$.

\begin{tabular}{|c|c|c|c|c|}
\hline Serum 25(OH) $\mathbf{D}^{2}$ & $\begin{array}{c}\text { Model } 1 \\
\geq 40^{\circ} \mathrm{N} ; \text { No adjustments }{ }^{3} \\
\end{array}$ & $\begin{array}{c}\text { Model } 2 \\
\geq 40^{\circ} \mathrm{N} ; \text { Adjusted }^{4} \\
\end{array}$ & $\begin{array}{c}\text { Model } 3 \\
\geq 50^{\circ} \mathrm{N} ; \text { No adjustments } \\
\end{array}$ & $\begin{array}{c}\text { Model } 4 \\
\geq 50^{\circ} \mathrm{N} ; \text { Adjusted }^{6} \\
\end{array}$ \\
\hline All & $n=1429$ & $n=1429$ & $n=1139$ & $n=1139$ \\
\hline$\geq 25 \mathrm{nmol} / \mathrm{L}$ & $5.9(3.9,9.0)$ & $2.0(1.3,3.4)$ & $6.3(4.0,9.7)$ & $2.5(1.5,4.3)$ \\
\hline$\geq 30 \mathrm{nmol} / \mathrm{L}$ & $12.2(8.2,18.4)$ & $4.5(2.8,7.5)$ & $12.1(7.9,19.2)$ & $5.1(3.1,8.5)$ \\
\hline$\geq 50 \mathrm{nmol} / \mathrm{L}$ & $92.3(60.3,146.0)$ & $43.6(27.7,70.5)$ & $75.1(48.1,123.5)$ & $37.9(23.3,69.7)$ \\
\hline Adults (aged 18-89) & $n=911$ & $n=911$ & $n=911$ & $n=665$ \\
\hline$\geq 25 \mathrm{nmol} / \mathrm{L}$ & $8.4(4.2,18.2)$ & $2.2(1.0,4.4)$ & $9.6(4.7,21.4)$ & $3.0(1.3,7.5)$ \\
\hline$\geq 30 \mathrm{nmol} / \mathrm{L}$ & $18.0(9.5,39.7)$ & $5.2(2.7,10.9)$ & $18.9(9.4,42.7)$ & $6.4(2.8,15.3)$ \\
\hline$\geq 50 \mathrm{nmol} / \mathrm{L}$ & $156.4(76.7,280.8)$ & $60.2(31.2,120.4)$ & $127.9(63.9,271.0)$ & $52.0(23.6,135.9)$ \\
\hline Children (aged 2-17) & $n=518$ & $n=518$ & $n=518$ & $n=474$ \\
\hline$\geq 25 \mathrm{nmol} / \mathrm{L}$ & $3.4(2.9,4.0)$ & $1.9(1.3,2.9)$ & $3.6(3.0,4.2)$ & $2.1(1.3,3.7)$ \\
\hline$\geq 30 \mathrm{nmol} / \mathrm{L}$ & $6.3(5.3,7.2)$ & $3.7(2.5,5.6)$ & $6.5(5.6,7.6)$ & $4.1(2.5,7.0)$ \\
\hline$\geq 50 \mathrm{nmol} / \mathrm{L}$ & $33.8(28.5,42.0)$ & $24.4(16.8,38.2)$ & $34.3(28.4,43.3)$ & $26.1(16.4,45.4)$ \\
\hline
\end{tabular}

${ }^{1}$ Based on a 1-stage IPD log-log model using data from RCTs performed during winter (at either $\geq 40^{\circ} \mathrm{N}$ or $\geq 50^{\circ} \mathrm{N}$ ) and which related serum $25(\mathrm{OH}) \mathrm{D}$ concentration as a function of vitamin D intake (with or without adjustment). 95\% CIs for the lower prediction limits were obtained using bias-corrected bootstrap based on 1000 replications.

${ }^{2}$ Cut-off of $\geq 25 \mathrm{nmol} / \mathrm{L}$ used by UK Scientific Advisory Committee on Nutrition [22]; cut-off of $\geq 30 \mathrm{nmol} / \mathrm{L}$ used by Institute of Medicine [IOM] [4], Nordic Nutrition Recommendations [NNR] [21] and European Food Safety Authority [EFSA] [22] to define deficiency, and cut-off of $\geq 50$ nmol/L used by IOM, NNR and EFSA to define threshold of adequacy.

${ }^{3}$ Model 1: RCTs performed in the latitude band of $40-63^{\circ} \mathrm{N}$; no adjustments to model.

${ }^{4}$ Model 2: RCTs performed in the latitude band of $40-63^{\circ} \mathrm{N}$; adjustment in model for baseline serum $25(\mathrm{OH}) \mathrm{D}$, age and BMI.

${ }^{5}$ Model 3: RCTs performed in the latitude band of $51-63^{\circ} \mathrm{N}$; no adjustments to model.

${ }^{6}$ Model 4: RCTs performed in the latitude band of $51-63^{\circ} \mathrm{N}$ adjustment in model for baseline serum $25(\mathrm{OH}) \mathrm{D}$, age and BMI. 
Table 3. Individual Participant Data (IPD) meta-analysis-derived dietary requirements for vitamin $\mathrm{D}(\mu \mathrm{g} /$ day) to maintain stated percentage of the population (percentile) at a serum $25(\mathrm{OH}) \mathrm{D}$ level at or above selected concentrations in participants residing between $40-63^{\circ} \mathrm{N}$ during winter ${ }^{l}$

\begin{tabular}{|c|c|c|c|c|}
\hline Serum 25(OH)D & 50 $^{\text {th }}$ Percentile $^{2}$ & 90 ${ }^{\text {th }}$ Percentile & 95 ${ }^{\text {th }}$ Percentile & 97.5.$^{\text {th }}$ Percentile $^{3}$ \\
\hline \multicolumn{5}{|l|}{ No adjustments } \\
\hline \multicolumn{5}{|l|}{ All $(n=1429)$} \\
\hline$\geq 25 \mathrm{nmol} / \mathrm{L}$ & - & $2.2(1.4,3.2)$ & $3.7(2.5,5.7)$ & $5.9(3.9,9.0)$ \\
\hline$\geq 30 \mathrm{nmol} / \mathrm{L}$ & - & $4.4(3.0,6.5)$ & $7.6(5.1,10.8)$ & $12.2(8.2,18.4)$ \\
\hline$\geq 50 \mathrm{nmol} / \mathrm{L}$ & $4.9(3.5,7.0)$ & $33.4(23.0,50.5)$ & $57.5(38.8,87.3)$ & $92.3(60.3,146.0)$ \\
\hline \multicolumn{5}{|l|}{ Adults $(n=991)$} \\
\hline$\geq 25 \mathrm{nmol} / \mathrm{L}$ & - & $2.6(1.3,4.7)$ & $4.8(2.4,9.5)$ & $8.4(4.2,18.2)$ \\
\hline$\geq 30 \mathrm{nmol} / \mathrm{L}$ & - & $5.5(3.0,9.9)$ & $10.4(5.4,20.7)$ & $18.0(9.5,39.7)$ \\
\hline$\geq 50 \mathrm{nmol} / \mathrm{L}$ & $5.0(2.8,8.4)$ & $47.2(25.3,91.4)$ & $89.6(46.7,183.7)$ & $156.4(76.7,280.8)$ \\
\hline \multicolumn{5}{|l|}{ Children $(n=518)$} \\
\hline$\geq 25 \mathrm{nmol} / \mathrm{L}$ & - & $1.8(1.5,2.1)$ & $2.5(2.1,3.0)$ & $3.4(2.9,4.0)$ \\
\hline$\geq 30 \mathrm{nmol} / \mathrm{L}$ & - & $3.3(2.8,3.8)$ & $4.6(4.0,5.3)$ & $6.3(5.3,7.2)$ \\
\hline$\geq 50 \mathrm{nmol} / \mathrm{L}$ & $5.1(4.6,5.6)$ & $17.5(15.3,20.1)$ & $24.9(21.2,29.7)$ & $33.8(28.5,42.0)$ \\
\hline \multicolumn{5}{|l|}{ Adjusted model } \\
\hline \multicolumn{5}{|l|}{ All $(n=1429)$} \\
\hline$\geq 25 \mathrm{nmol} / \mathrm{L}$ & - & $0.8(0.5,1.2)$ & $1.3(0.8,2.1)$ & $2.0(1.3,3.4)$ \\
\hline$\geq 30 \mathrm{nmol} / \mathrm{L}$ & - & $1.8(1.1,2.8)$ & $2.9(1.9,4.5)$ & $4.5(2.8,7.5)$ \\
\hline$\geq 50 \mathrm{nmol} / \mathrm{L}$ & $2.9(1.9,4.1)$ & $17.0(11.3,27.0)$ & $28.1(18.1,45.9)$ & $43.6(27.7,70.5)$ \\
\hline \multicolumn{5}{|l|}{ Adults $(n=911)$} \\
\hline$\geq 25 \mathrm{nmol} / \mathrm{L}$ & - & $0.7(0.4,1.4)$ & $1.3(0.6,2.4)$ & $2.2(1.0,4.4)$ \\
\hline$\geq 30 \mathrm{nmol} / \mathrm{L}$ & - & $1.8(0.9,3.2)$ & $3.1(1.6,6.3)$ & $5.2(2.7,10.9)$ \\
\hline$\geq 50 \mathrm{nmol} / \mathrm{L}$ & $2.6(1.4,4.5)$ & $20.2(10.9,39.6)$ & $36.2(19.8,76.0)$ & $60.2(31.2,120.4)$ \\
\hline \multicolumn{5}{|l|}{ Children $(n=518)$} \\
\hline$\geq 25 \mathrm{nmol} / \mathrm{L}$ & - & $1.0(0.7,1.4)$ & $1.4(0.9,2.1)$ & $1.9(1.3,2.9)$ \\
\hline$\geq 30 \mathrm{nmol} / \mathrm{L}$ & - & $2.0(1.4,2.7)$ & $2.8(1.9,4.0)$ & $3.7(2.5,5.6)$ \\
\hline$\geq 50 \mathrm{nmol} / \mathrm{L}$ & $3.8(2.7,5.1)$ & $12.8(9.1,17.7)$ & $18.0(12.3,27.1)$ & $24.4(16.8,38.2)$ \\
\hline
\end{tabular}

${ }^{I}$ Results based on a 1-stage IPD log-log model which related serum 25(OH)D concentration as a function of vitamin $\mathrm{D}_{3}$ intake both unadjusted and adjusted for baseline serum $25(\mathrm{OH}) \mathrm{D}$ (mean), age (mean) and BMI (mean). 95\% CIs for the lower prediction limits were obtained using bias-corrected bootstrap based on 1000 replications.

${ }^{2}$ The vitamin D intake that will maintain serum $25(\mathrm{OH}) \mathrm{D}$ concentrations in $50 \%$ of individuals above $50 \mathrm{nmol} / \mathrm{L}$ during winter, representing an EAR at that threshold; this is not appropriate to do at the 25 and $30 \mathrm{nmol} / \mathrm{L}$ thresholds.

${ }^{3}$ The vitamin $\mathrm{D}_{3}$ intake that will maintain serum $25(\mathrm{OH}) \mathrm{D}$ concentrations in $97.5 \%$ of individuals above the indicated cut-off concentration during winter, representing a Recommended dietary allowance (RDA). 
Table 4. Projected upper $97.5^{\text {th }}$ percentile serum 25(OH)D concentrations achieved at vitamin $\mathrm{D}$ intake requirement estimates from the unadjusted and adjusted models ${ }^{1}$

\begin{tabular}{|c|c|c|}
\hline $\begin{array}{l}\text { Requirement percentile } \\
\text { (at specified threshold) }\end{array}$ & $\begin{array}{l}\text { Vitamin D intake } \\
\text { requirement }(\mu \mathrm{g} / \mathrm{d})^{2}\end{array}$ & $\begin{array}{l}\text { Projected upper } 97.5^{\text {th }} \text { percentile serum } \\
25(\mathrm{OH}) \mathrm{D} \text { concentrations }(\mathrm{nmol} / \mathrm{L})\end{array}$ \\
\hline \multicolumn{3}{|l|}{ Unadjusted model } \\
\hline $\begin{array}{l}\geq 25 \mathrm{nmol} / \mathrm{L}: \\
90^{\text {th }} \text { Percentile } \\
95^{\text {th }} \text { Percentile } \\
97.5^{\text {th }} \text { Percentile }\end{array}$ & $\begin{array}{l}2.2 \\
3.7 \\
5.9\end{array}$ & $\begin{array}{c}85.4 \\
97.4 \\
109.6 \\
\end{array}$ \\
\hline $\begin{array}{l}\geq 30 \mathrm{nmol} / \mathrm{L}: \\
90^{\text {th }} \text { Percentile } \\
95^{\text {th }} \text { Percentile } \\
\text { 97. } .^{\text {th }} \text { Percentile }\end{array}$ & $\begin{array}{c}4.4 \\
7.6 \\
12.2 \\
\end{array}$ & $\begin{array}{l}101.8 \\
116.9 \\
131.8 \\
\end{array}$ \\
\hline $\begin{array}{l}\geq 50 \mathrm{nmol} / \mathrm{L}: \\
90^{\text {th }} \text { Percentile } \\
95^{\text {th }} \text { Percentile } \\
97.5^{\text {th }} \text { Percentile }\end{array}$ & $\begin{array}{l}33.4 \\
57.5 \\
92.3\end{array}$ & $\begin{array}{l}170.1 \\
195.2 \\
220.2\end{array}$ \\
\hline Adjusted model & & \\
\hline $\begin{array}{l}\geq 25 \mathrm{nmol} / \mathrm{L}: \\
90^{\text {th }} \text { Percentile } \\
95^{\text {th }} \text { Percentile } \\
\text { 97. } .^{\text {th }} \text { Percentile }\end{array}$ & $\begin{array}{l}0.8 \\
1.3 \\
2.0 \\
\end{array}$ & $\begin{array}{l}69.4 \\
77.4 \\
85.3 \\
\end{array}$ \\
\hline $\begin{array}{l}\geq 30 \mathrm{nmol} / \mathrm{L}: \\
90^{\text {th }} \text { Percentile } \\
95^{\text {th }} \text { Percentile } \\
97.5^{\text {th }} \text { Percentile }\end{array}$ & $\begin{array}{l}1.8 \\
2.9 \\
4.5\end{array}$ & $\begin{array}{r}83.3 \\
92.8 \\
102.5\end{array}$ \\
\hline $\begin{array}{l}\geq 50 \mathrm{nmol} / \mathrm{L}: \\
90^{\text {th }} \text { Percentile } \\
95^{\text {th }} \text { Percentile } \\
97.5^{\text {th }} \text { Percentile }\end{array}$ & $\begin{array}{l}17.0 \\
28.1 \\
43.6\end{array}$ & $\begin{array}{r}138.4 \\
155.1 \\
171.3 \\
\end{array}$ \\
\hline $\begin{array}{l}{ }^{l} \text { Projected upper } 97.5^{\text {th }} \text { pe } \\
\text { which related serum } 25(C \\
\text { adjusted for baseline seru }\end{array}$ & $\begin{array}{l}\text { e serum } 25(\mathrm{OH}) \mathrm{D} \text { rest } \\
\text { oncentration as a func } \\
\mathrm{H}) \mathrm{D} \text { (mean), age (me }\end{array}$ & $\begin{array}{l}\text { Its based on the 1-stage IPD log-log models } \\
\text { ion of vitamin } \mathrm{D}_{3} \text { intake both unadjusted and } \\
\text { in) and BMI (mean). }\end{array}$ \\
\hline
\end{tabular}




\section{Legends for Figures}

Figure 1. PRISMA (Preferred Reporting Items for Systematic Reviews and Meta-Analyses) flow diagram for study selection procedure.

*ClinicalTrials.gov, Cochrane Central Register of Controlled Trials, and the International Standard Randomized Controlled Trials Number registries.

Figure 2. The relation between serum 25-hydroxyvitamin D $(25(\mathrm{OH}) \mathrm{D})$

concentrations (in extended winter) and total vitamin $\mathrm{D}$ intake in healthy individuals aged 2-89 years living between $40^{\circ} \mathrm{N}$ and $63^{\circ} \mathrm{N}$ based on individual participant data (IPD) ( $n=1429$ individuals). The solid central diagonal lines correspond to the fitted regression lines based on one-stage IPD meta-analysis (unadjusted model (Panel A) and model adjusted for age, BMI and baseline 25(OH)D (Panel B)) and the corresponding $95 \%$ prediction bands are shown in gray. Note: the fitted curve and the 95\% confidence band were back-transformed but are displayed in the graphs using logarithmic axes in keeping with the log-log model. The black horizontal lines in each panel represent the serum $25(\mathrm{OH}) \mathrm{D}$ thresholds of 30 and $50 \mathrm{nmol} / \mathrm{L}$ relating to risk of vitamin D deficiency and inadequacy, respectively. Overlapping dots make some appear more darkly coloured. 

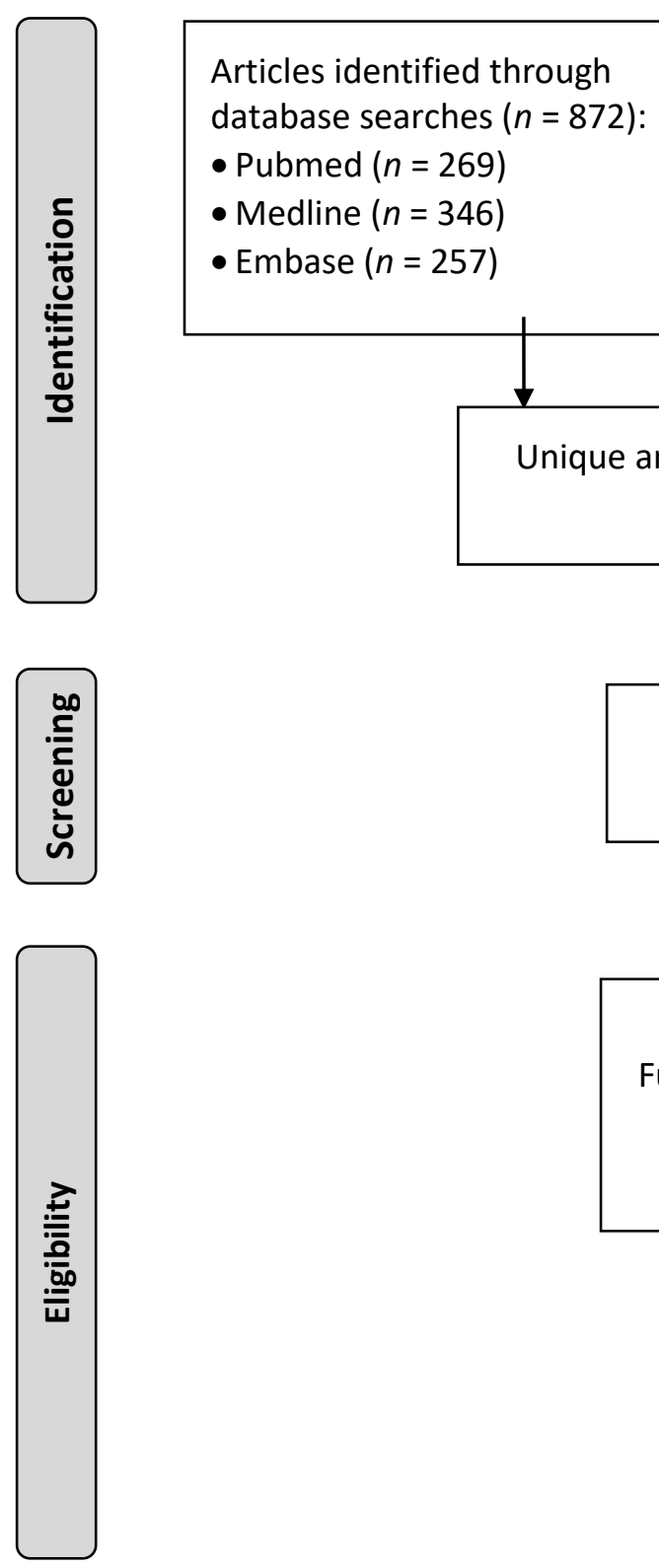

Additional studies identified through other sources, including three trial registries* $(n=2)$

Unique articles identified after duplicates removed $(n=644)$

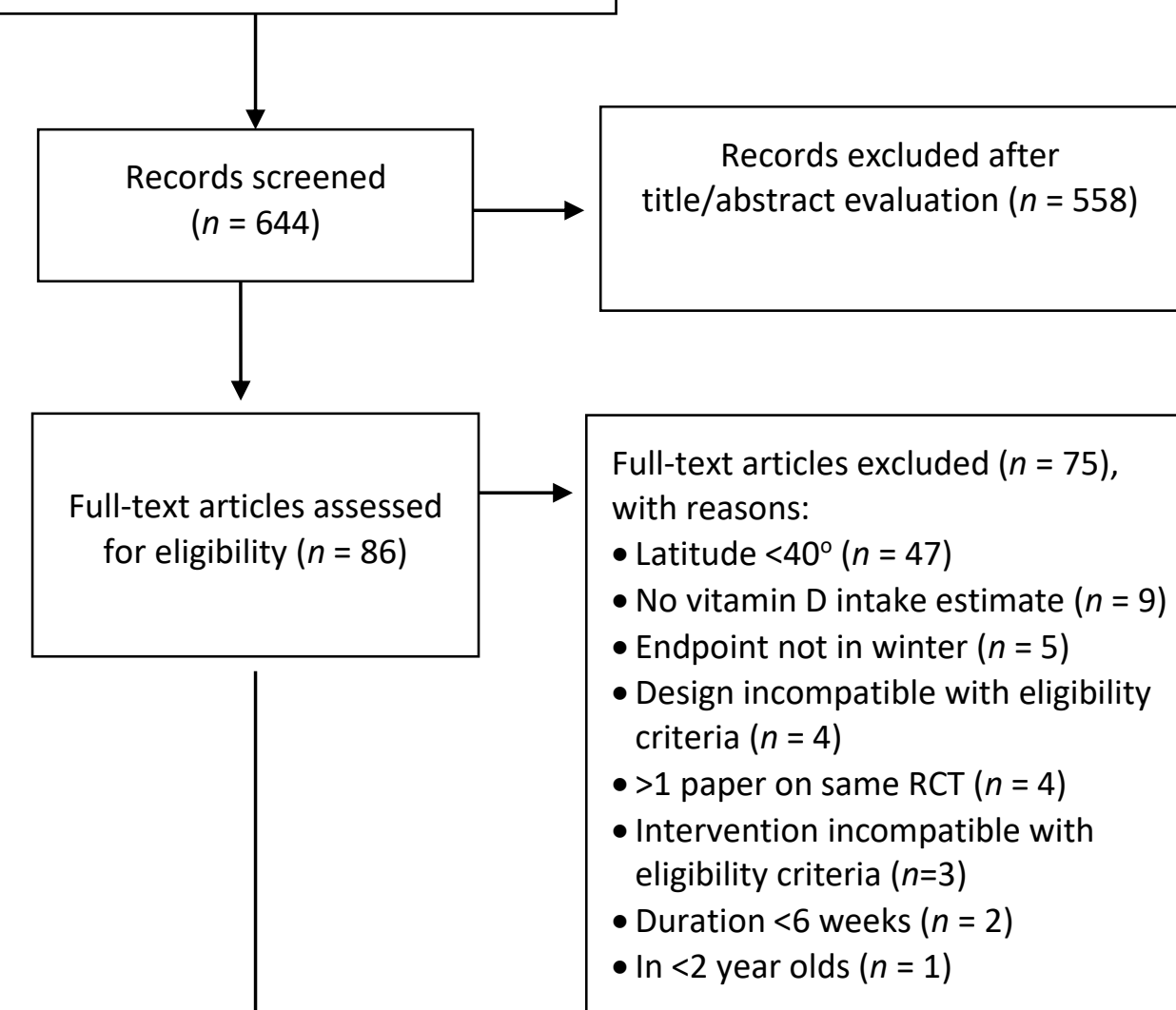

Studies invited to IPD metaregression analysis $(n=11)$ and studies accepting ( $n=11$; total number of individual participants included = 1429)

Figure 1. PRISMA (Preferred Reporting Items for Systematic Reviews and Meta-Analyses) flow diagram for study selection procedure.

*ClinicalTrials.gov, Cochrane Central Register of Controlled Trials, and the International Standard Randomized Controlled Trials Number registries. 
A.

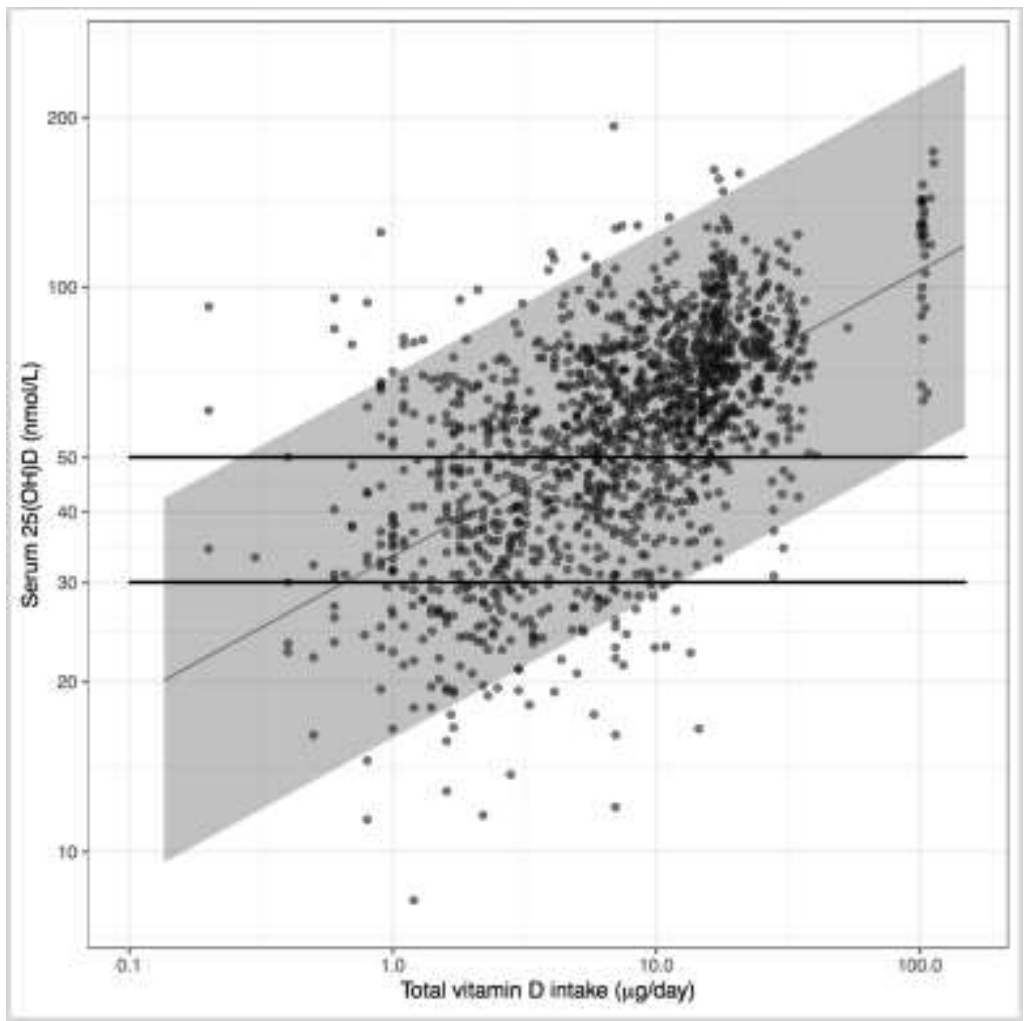

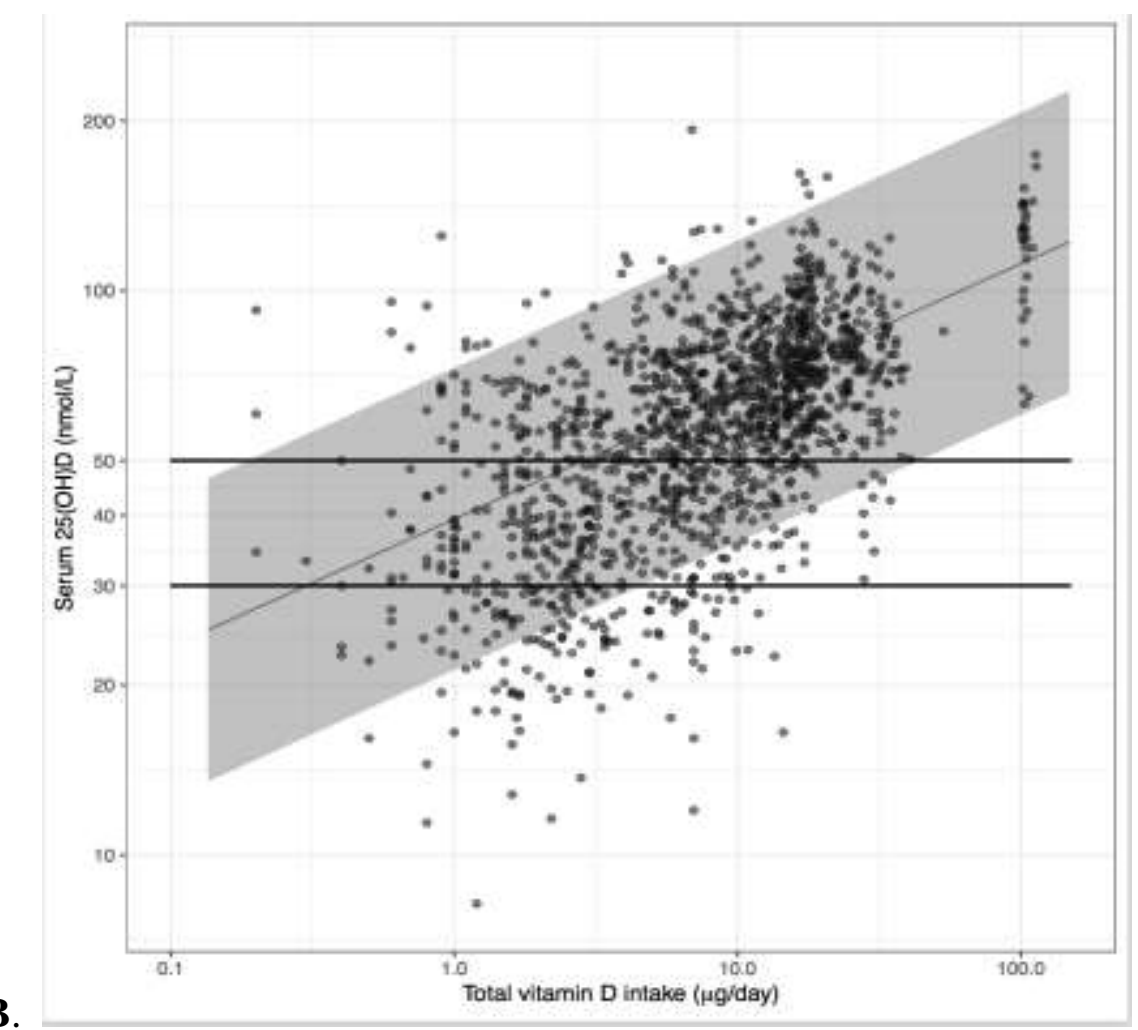

B.

Figure 2. The relation between serum 25-hydroxyvitamin $\mathrm{D}(25(\mathrm{OH}) \mathrm{D})$ concentrations (in extended winter) and total vitamin $\mathrm{D}$ intake in healthy individuals aged 2-89 years living between $40^{\circ} \mathrm{N}$ and $63^{\circ} \mathrm{N}$ based on individual participant data (IPD) ( $n=1429$ individuals). The solid central diagonal lines correspond to the fitted regression lines based on one-stage IPD meta-analysis (unadjusted model (Panel A) and model adjusted for age, BMI and baseline 25(OH)D (Panel B)) and the corresponding 95\% prediction bands are shown in gray. Note: the fitted curve and the 95\% confidence band were back-transformed but are displayed in the graphs using logarithmic axes in keeping with the log-log model. The black horizontal lines in each panel represent the serum $25(\mathrm{OH}) \mathrm{D}$ thresholds of 30 and $50 \mathrm{nmol} / \mathrm{L}$ relating to risk of vitamin D deficiency and inadequacy, respectively. Overlapping dots make some appear more darkly coloured. 